\title{
Dissolved iron (II) in the Baltic Sea surface water and implications for cyanobacterial bloom development
}

\author{
E. Breitbarth ${ }^{1,2,3}$, J. Gelting ${ }^{2}$, J. Walve ${ }^{4}$, L. J. Hoffmann ${ }^{1,3,5}$, D. R. Turner ${ }^{1}$, M. Hassellöv ${ }^{1}$, and J. Ingri ${ }^{2}$ \\ ${ }^{1}$ Department of Chemistry, Analytical and Marine Chemistry, University of Gothenburg, Kemivägen 10, \\ 41296 Gothenburg, Sweden \\ ${ }^{2}$ Luleå University of Technology, Division of Applied Geology, 97187 Luleå, Sweden \\ ${ }^{3}$ Department of Chemistry, University of Otago, P.O. Box 56, Dunedin 9054, New Zealand \\ ${ }^{4}$ Department of Systems Ecology, Stockholm University, 10691 Stockholm, Sweden \\ ${ }^{5}$ Department of Plant and Environmental Sciences, University of Gothenburg, P.O. Box 461, 40530 Gothenburg, Sweden
}

Received: 28 February 2009 - Published in Biogeosciences Discuss.: 6 April 2009

Revised: 22 September 2009 - Accepted: 1 October 2009 - Published: 4 November 2009

\begin{abstract}
Iron chemistry measurements were conducted during summer 2007 at two distinct locations in the Baltic Sea (Gotland Deep and Landsort Deep) to evaluate the role of iron for cyanobacterial bloom development in these estuarine waters. Depth profiles of $\mathrm{Fe}(\mathrm{II})$ were measured by chemiluminescent flow injection analysis (CL-FIA). Up to $0.9 \mathrm{nmol} \mathrm{Fe}(\mathrm{II}) \mathrm{L}^{-1}$ were detected in light penetrated surface waters, which constitutes up to $20 \%$ to the dissolved Fe pool. This bioavailable iron source is a major contributor to the $\mathrm{Fe}$ requirements of Baltic Sea phytoplankton and apparently plays a major role for cyanobacterial bloom development during our study. Measured Fe(II) half life times in oxygenated water exceed predicted values and indicate organic $\mathrm{Fe}$ (II) complexation. Potential sources for Fe(II) ligands, including rainwater, are discussed. Fe(II) concentrations of up to $1.44 \mathrm{nmol} \mathrm{L}^{-1}$ were detected at water depths below the euphotic zone, but above the oxic anoxic interface. Mixed layer depths after strong wind events are not deep enough in summer time to penetrate the oxic-anoxic boundary layer. However, $\mathrm{Fe}$ (II) from anoxic bottom water may enter the sub-oxic zone via diapycnal mixing and diffusion.
\end{abstract}

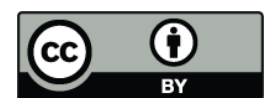

Correspondence to: E. Breitbarth (ebreitbarth@chemistry.otago.ac.nz)

\section{Introduction}

\subsection{Iron and marine biogeochemistry}

Iron and other trace metals have essential roles in the biosphere, serving as the active centers of enzymes and are responsible for electron transfer reactions in many different vital biological processes. The large scale multi-disciplinary iron enrichment experiments in HNLC (High Nutrient Low Chlorophyll) regions demonstrated the role of iron and colimitation with factors such as light and macronutrients on marine biogeochemical cycles (de Baar et al., 2005, 2007). Generally, iron concentrations are orders of magnitude higher in coastal and estuarine waters such as the Baltic Sea, but iron control of primary production has still been observed. Iron bioavailability for marine algae is largely regulated by organic complexation and observations of iron control in nutrient replete coastal waters indicate that due to strong DOM-Fe complexation, iron limitation is not confined to the classic HNLC regions (Bruland et al., 2001; Hutchins et al., 1998; Öztürk et al., 2002). Therefore, the paradigm of generally iron-replete and iron-deficient systems has been refined for some coastal areas, especially with respect to seasonal variations in iron speciation.

In seawater, iron occurs in two oxidation states, $\mathrm{Fe}(\mathrm{II})$ and $\mathrm{Fe}(\mathrm{III})$. Thermodynamics strongly favor Fe(III) in the modern oxygenated ocean, whereas its solubility is low and in the open ocean largely maintained at sufficient concentrations for phytoplankton growth by organic complexation (Bruland and Lohan, 2003; Rue and Bruland, 1995). In coastal and

Published by Copernicus Publications on behalf of the European Geosciences Union. 
especially lower salinity estuarine waters organic and inorganic iron colloids (stabilized by organic matter), play an important role (e.g. Gustafsson et al., 2000; Sander et al., 2004; Croot and Johansson, 2000; Wells et al., 2000; Sholkovitz and Coplan, 1981; Brügmann et al., 1998). Fe(II) is highly soluble but rapidly re-oxidized to $\mathrm{Fe}(\mathrm{III})$ in oxygenated seawater (Santana-Casiano et al., 2006). Oxygen and hydrogen peroxide are the main oxidants of $\mathrm{Fe}(\mathrm{II})$ in seawater, while seawater $\mathrm{pH}$ and water temperature strongly affect $\mathrm{Fe}$ (II) oxidation rates by $\mathrm{O}_{2}$ and $\mathrm{H}_{2} \mathrm{O}_{2}$ (Croot et al., 2001; Millero and Sotolongo, 1989; Millero et al., 1987). Direct photolysis of organic Fe(III) complexes in surface water can be a significant source of $\mathrm{Fe}$ (II) in seawater (Barbeau et al., 2003; Croot et al., 2008). Further key processes include mediation and uptake by phytoplankton cells (e.g. Maldonado and Price, 1999, 2000, 2001; Kustka et al., 2005; Rose et al., 2005), reduction in acidic food vacuoles during grazing (Barbeau et al., 1996), and photoreduction of colloidal Fe (Johnson et al., 1994; Wells et al., 1991). Fe(II) is considered both more labile and bioavailable than complexed Fe(III). Uptake of $\mathrm{Fe}(\mathrm{II})$ does not require energetically costly surface reduction of iron at the cell membrane, or across membrane transport of specific iron ligand complexes and also forms an intermediate in iron acquisition systems of eukaryotic phytoplankton (Morel et al., 2008; Shaked et al., 2005; Salmon et al., 2006; Sunda, 2001; Anderson and Morel, 1982). Thus its presence may imply favorable growth conditions for marine phytoplankton and particularly an ecological advantage for surface dwelling nitrogen fixing cyanobacteria over other phytoplankton if concentrations of other inorganic nitrogen sources are low.

\subsection{The Baltic Sea, cyanobacterial blooms, and iron}

The Baltic Sea (Fig. 1) is the worlds largest estuary and forms a unique and multifaceted coastal and marine environment due to strong physico-chemical gradients, land influences (run-off water, riverine and melt-water input), and episodic oceanic water inflow. The Baltic Sea is extensively used as a waterway, fishing ground, and for recreational purposes. Thus it is of high socio-economic value to its riparian nations. The Baltic Sea ecosystem as a whole has gained increasing attention and monitoring studies and satellite observations have shown varying extents of surface slicks with massive cyanobacterial abundances over the past years (Kahru et al., 2007; Hansson, 2007). The Baltic Proper, with the Gotland Basin in its center and the Landsort Deep station on its northwestern margin, is considered as the origin of cyanobacterial bloom development during summers due to favorable conditions for their growth with regard to salinity and dissolved inorganic nitrogen: dissolved inorganic phosphate (DIN:DIP) ratios seasonally as low as 1 (Stal et al., 2003).

Cyanobacterial nitrogen fixation accounts for $20-40 \%$ of the nitrogen input into the Baltic Sea (Larsson et al., 2001). Low DIN:DIP ratios favor nitrogen fixation and cyanobacte-

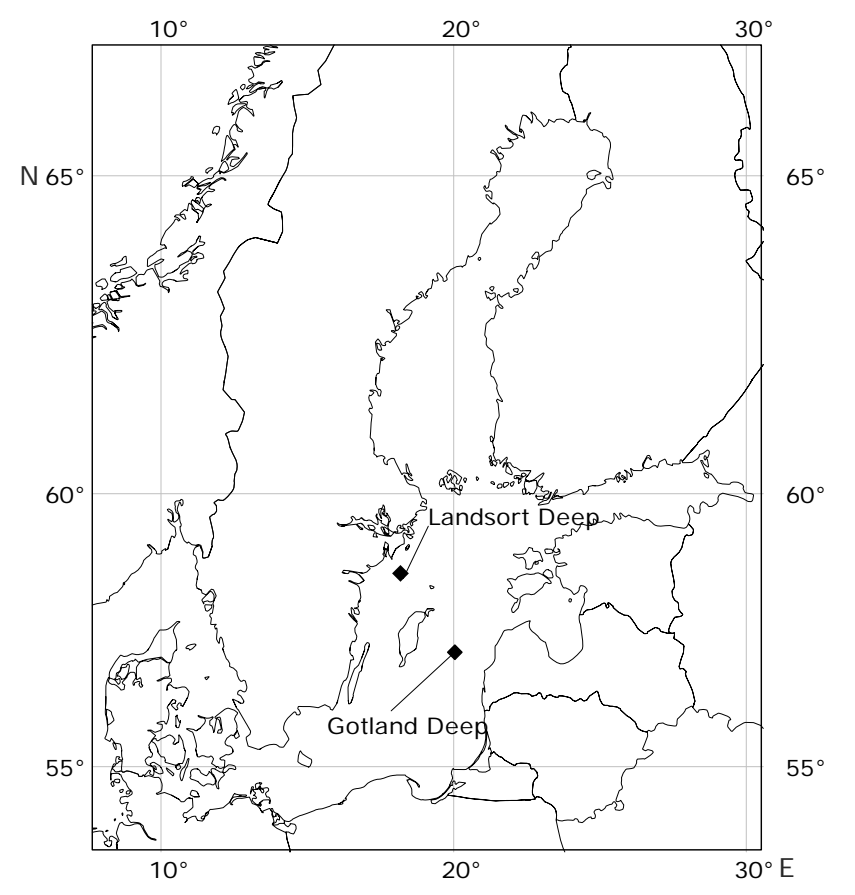

Fig. 1. Map of the Baltic Sea with the two sampling sites: Landsort Deep $\left(58^{\circ} 36^{\prime} \mathrm{N}, 18^{\circ} 14^{\prime} \mathrm{E}\right)$ and Gotland Deep $\left(57^{\circ} 18^{\prime} \mathrm{N} ; 20^{\circ} 04^{\prime} \mathrm{E}\right)$. Figure produced using Panmap (Pangaea).

rial blooms generally develop over the course of the summer after eukaryotic phytoplankton has diminished dissolved nitrogen sources. On the one hand, the increase in cyanobacteria occurrence and density has been attributed to eutrophication (Finni et al., 2001). Alternatively, phosphorus release from up-welled deep waters may stimulate cyanobacteria growth (Stal et al., 2003; Kononen et al., 1996). Iron as a potentially limiting nutrient for cyanobacterial bloom development and nitrogen fixation in the Baltic Sea has been suggested (Stal et al., 1999; Stolte et al., 2006). $\mathrm{N}_{2}$ fixing cyanobacteria have a $2.5-11$ fold higher iron demand than other phytoplankton (Kustka et al., 2003a, 2003b, 2002; Sanudo-Wilhelmy et al., 2001) and thus cyanobacterial bloom development may to some extent be controlled by iron bioavailability. Coastal waters can have a high load of dissolved organic matter (DOM) and photoreduction of $\mathrm{Fe}$ bound to DOM and specifically also to phytoplankton exudates after previous spring blooms can yield higher $\mathrm{Fe}(\mathrm{II})$ concentrations than in open ocean water. Further, vertical mixing can introduce high loads of $\mathrm{Fe}(\mathrm{II})$ from anoxic sediments into coastal surface water (Kuma et al., 1992, 1995). A fraction of iron in lower salinity waters as in the Baltic Proper is in colloidal form, accounting for $5-10 \%$ of the total Fe concentration during this study (Gelting et al., 2009), which further can be subject to photochemical reduction and a source of Fe(II) (Wells et al., 1991; Rijkenberg et al., 2006a). 
The distributions of trace metals in surface waters of the Baltic Sea, including studies along the north-south salinity gradient, and in depth profiles across the redox-cline that divide the water column in an oxygenated and phosphate depleted surface zone and an anoxic, metal and phosphate rich deep water layer have been addressed (Brügmann et al., 1992; Pohl and Hennings, 2005; Pohl et al., 2004, 2006; Dyrssen and Kremling, 1990). Brügmann et al. (1998) and Pohl and Hennings (1999) have described metal speciation changes after the 1993/1994 salt water inflow and resulting bottom water oxygenation events. However, deep water anoxic conditions reestablished and no salt water inflow event was preceding our field season in the summer of 2007. Further, Ingri et al. (2004) showed a shift in trace metal speciation from the low molecular weight (LMW) fraction into the colloidal and particulate phase over the course of a spring bloom, which would result in seasonal depletion of potentially bioavailable LMW bound trace metals. The Landsort Deep (LD) and Gotland Deep (GD) regions of the Baltic Sea are characterized by surface dissolved Fe concentrations in the low nanomolar range (Strady et al., 2008; Gelting et al., 2009). Yet, to date no specific information on iron complexation and depth profiles of Fe(II) in the Baltic Sea has been published.

\subsection{Aim of the study}

In this study, we address the dynamics of iron speciation in oxygenated water layers over the course of the Nordic summer at these two locations. The approach focuses on Fe(II) and addresses the main sources of Fe(II) in surface water (photoreduction and rainfall), next to physico-chemical parameters (irradiation, temperature) and main oxidants (oxygen, hydrogen peroxide), as well as indicators for consumption (chlorophyll- $a$, cyanobacteria biomass). Depth profiles also aim to indentify sources of $\mathrm{Fe}(\mathrm{II})$ to deeper water layers and set them in context of additional parameters such as $\mathrm{pH}$, total phosphate $\left(\mathrm{PO}_{4}\right)$, and water column mixing in order to evaluate if $\mathrm{Fe}$ (II) rich water masses from deeper oxygen depleted layers can be mixed into surface waters after storm events (Fig. 2). We hypothesize that iron has a regulatory function during cyanobacterial bloom development in the Baltic Sea and particularly that Fe(II) concentrations may play an important role.

\section{Methods}

\subsection{Cruise locations}

A total of five cruises were conducted using the R/V Fyrbyggaren between 20 June and 14 August 2007 to two stations in the Baltic Sea. Landsort Deep (LD, $459 \mathrm{~m}$ depth, $58^{\circ} 36^{\prime} \mathrm{N}$, $18^{\circ} 14^{\prime} \mathrm{E}$ ) is located close to the Swedish east coast and Gotland Deep (GD, $249 \mathrm{~m}$ depth, $57^{\circ} 18^{\prime} \mathrm{N} ; 20^{\circ} 04^{\prime} \mathrm{E}$ ) is situated in the center of the main basin of the Baltic Proper (Fig. 1).
Both stations are characterized by a clear redox-cline at intermediate depth. Fresher estuarine Baltic water on the surface overlays more saline water at depth. The deep water is anoxic after extended periods of time with limited exchange with the upper layer. It typically is rich in macro nutrients, especially $\mathrm{PO}_{4}$, and metal concentrations and characterized by hydrogen sulfide formation after microbial oxygen consumption. However, influx events of oxic marine water from the Skagerrak through the Danish Straits can perturb and oxygenate the deep water layer, as for example recorded for 1993/94, 1997, and 2003/04 (Meier, 2007). Such influx and oxygenation events can largely alter the nutrient and metal chemistries and result in precipitation of metal salts. This, however, was not the case during our study.

\subsection{Seawater sampling and sample processing}

Surface water samples ( $5 \mathrm{~m}$ depth) were obtained using trace metal cleaned polyethylene (PE) tubing that was suspended by a $16 \mathrm{~m}$ plastic mast from the bow of the vessel. The vessel steamed at speed of $1 \mathrm{kn}$ into the wind during surface sampling to minimize the risk of contamination by the ship. The sampled water was transported via a peristaltic pump into a laminar flow bench inside a laboratory container, where all sample handling took place. Water for measurements of dissolved iron (DFe), iron ligand titrations was filtered through trace metal cleaned $0.22 \mu \mathrm{m}$ membranes $(142 \mathrm{~mm}$ diameter, Millipore mixed cellulose ester, GSWP14250). Further, unfiltered samples were taken for total iron (TFe) analysis. All $\mathrm{DFe}$ and $\mathrm{DFe}$ samples were acidified to a final concentration of $0.1 \%$ quartz distilled $\mathrm{HNO}_{3}$ within hours after sampling. Depth profiles were sampled using individual pre-washed all plastic Niskin bottles with elastic silicone bands as the closure mechanism.

Samples for $\mathrm{Fe}(\mathrm{II})$ and hydrogen peroxide $\left(\mathrm{H}_{2} \mathrm{O}_{2}\right)$ analysis were taken from the Niskin bottles immediately after retrieval on deck. Sampling was performed in a similar manner as common for dissolved gases (Hansen, 1999), with the $\mathrm{Fe}(\mathrm{II}) / \mathrm{H}_{2} \mathrm{O}_{2}$ samples being the first taken from the Niskin bottles. A $50 \mathrm{~mL}$ PE syringe pre-fitted with a pre-washed $0.45-\mu \mathrm{m}$-pore size PVDF membrane (Sterivex-HV, Millipore, protected by a re-closable Minigrip plastic bag) was used as the sampling vessel. The plunger was removed and the syringe was filled from the plunger end. In order to avoid oxygen introduction, the syringe was carefully filled allowing the water to overflow for approximately $10 \mathrm{~s}$. A piece of silicone tubing attached to the nozzle of the Niskin bottle was used to pass the water into the syringe barrel while rising the end of the silicone tubing to maintain its opening just below the water surface. Then the plunger was refitted into the syringe, while carefully pressing the meniscus of the top water layer aside and thus not introducing air bubbles. Subsequently, the sample was pushed through the filter and split into two PE vessels after discarding the first $10 \mathrm{~mL}$. For $\mathrm{Fe}(\mathrm{II})$ analysis, the FIA sampling line was already positioned 


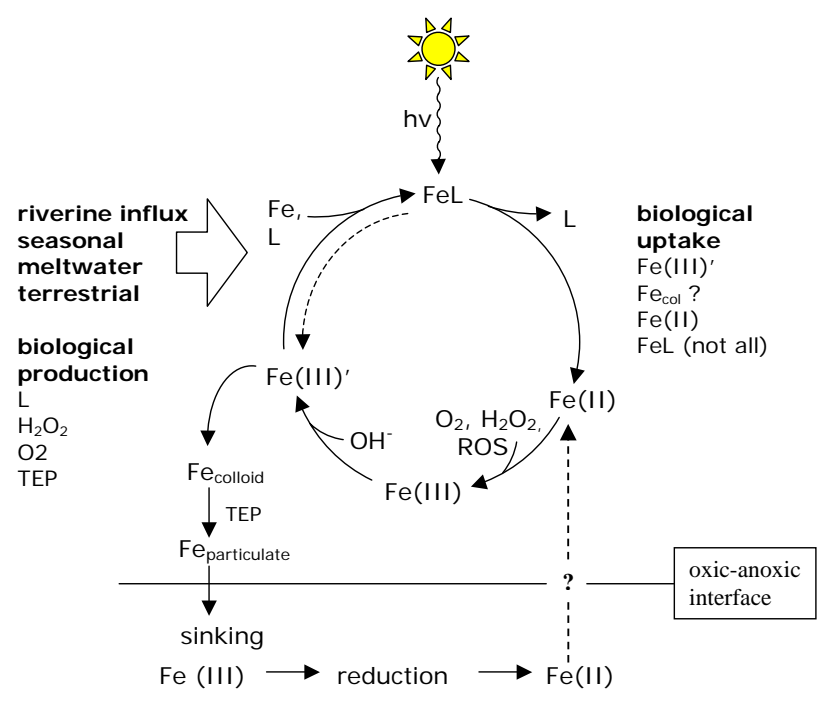

Fig. 2. Proposed Fe cycle for the Baltic Sea at Gotland Deep (image modified based on Sunda (2001) and Croot et al., 2005).

at the bottom of the PE vessel and analysis was started immediately, performing 5 successive analysis cycles. Sampling was always done inside a working container, and was thus shielded from sun-light and rain. Fe(II) concentrations were determined within the shortest time possible, usually within four minutes after closing the Niskin bottles in oxygenated surface water. The exact timing from bottle closing to analysis was noted. The chemiluminescent signal decay was fitted to an exponential function, thus allowing to calculate the $\mathrm{Fe}(\mathrm{II})$ concentration at the time of closing the Niskin bottle at the sampling depth. Individual Niskin casts at each depth were performed throughout the oxygenated water layer, while deep sampling in the anoxic zone was done in one cast. Tapping for anoxic deep water took place maximum one hour after closing the Niskin bottles at depth and the bottles remained sealed until $\mathrm{Fe}(\mathrm{II}) / \mathrm{H}_{2} \mathrm{O}_{2}$ sampling took place. Measurements of anoxic samples showed no signal decay and hence demonstrate that oxygen perturbation of the samples between bottle closure and analysis as well as during analysis was minimal. All sampling for Fe(II) took place during day-light, except for the LD profile on 4 July which was recorded at mid-night.

Samples for dissolved oxygen were taken immediately after the $\mathrm{Fe}(\mathrm{II}) / \mathrm{H}_{2} \mathrm{O}_{2}$ samples. $\mathrm{H}_{2} \mathrm{O}_{2}$ samples were stored in the dark for a minimum of two hours prior to analysis. $\mathrm{Fe}(\mathrm{II})$ profiles were obtained on 4 July and 1 August, 2007, at the Landsort Deep station and on 20 June, 20 July, 2 August, and 14 August, 2007, at Gotland Deep. $\mathrm{H}_{2} \mathrm{O}_{2}$ profiles were measured 1 August, as well as on 20 July and 2 August, 2007, at Landsort Deep and Gotland Deep, respectively.

\section{$2.3 \quad \mathrm{Fe}(\mathrm{II})$ analysis}

Seawater was analyzed for its Fe(II) content based on Croot and Laan (2002) using Chemiluminescent Flow Injection Analysis (CL-FIA) with the reagent Luminol. Luminol (5-amino-2,3-dihydro-1,4-phthalazine-dione, Sigma BioChemika), Hydrochloric acid (HCL, 30\%, Merck suprapur), Ammonia solution $\left(\mathrm{NH}_{4} \mathrm{OH}, 25 \%\right.$, Fluka trace select), and sodium carbonate $\left(\mathrm{Na}_{2} \mathrm{CO}_{3}\right.$, SigmaUltra) were used as received. Purified water (MilliQ, MQ) was used for all reagent preparations. The luminol reagent solution was allowed to stabilize overnight prior to use. The flow injection analyzer (FIA, Waterville Analytical, Maine, USA) was equipped with a $50 \mathrm{~cm}(1.2 \mathrm{~mL})$ sample loop. No sample preconcentration steps were applied. The effluent $\mathrm{pH}$ was monitored and adjusted to 10.3-10.4. A custom made Labview (National Instruments, USA) based software was used for instrument control and data acquisition. The measurements were calibrated using standard additions on seawater from the same stations that was aged to oxidize any $\mathrm{Fe}(\mathrm{II})$ present. In some cases residual Fe(II) was present in aged seawater and further calibrations were performed on water from the same cast that did not show an Fe(II) signal. Blank values ranged around the equivalent signal strength of $30 \mathrm{pmol} \mathrm{L}^{-1}$ in the Baltic waters. A $10 \mathrm{mmol} \mathrm{L}^{-1}$ primary $\mathrm{Fe}(\mathrm{II})$ standard solution was prepared from a Merck Titrisol Fe(II) standard in $0.1 \mathrm{~mol} \mathrm{~L}^{-1} \mathrm{HCL}$. Secondary standards were prepared immediately prior to use by serial dilution of the primary standard using $0.01 \mathrm{~mol} \mathrm{~L}^{-1} \mathrm{HCl}$. Standard additions to the samples were kept below $0.1 \%$ volume to reduce the effect of lowering the sample $\mathrm{pH}$ to a minimum. Estimated oxidation rates were calculated based on Millero et al. (1987) after approximating $[\mathrm{OH}]^{-}$using the the program CO2SYS (Lewis and Wallace, 1998) (see also Sect. 2.7). To evaluate Fe(II) oxidation rates in the samples, the chemiluminescent signal over time was naperian log transformed, which yields a linear signal decrease. The slope represents the Fe(II) oxidation rate constant $\left(k_{o x}\right)$ and converts to $\mathrm{Fe}(\mathrm{II})$ half life times $\left(t_{1 / 2}\right)$ (see also: Hopkinson and Barbeau, 2007).

\subsection{Hydrogen peroxide analysis}

$\mathrm{H}_{2} \mathrm{O}_{2}$ concentrations were determined by CL-FIA based on Yuan and Shiller (1999) using a second flow injection analyzer similar to the one described above. A $60 \mu \mathrm{L}$ reagent loop was used. The analysis utilizes the oxidation of luminol by $\mathrm{H}_{2} \mathrm{O}_{2}$ in an alkaline solution, which is catalyzed by cobalt(II). A $16.97 \mathrm{mmol} \mathrm{L}^{-1} \mathrm{Co}$ (II) standard solution $\left(\mathrm{CoCl}_{2}\right.$, Titrisol, Merck) was used to spike the luminol reagent in the $\mathrm{H}_{2} \mathrm{O}_{2}$ method to $60 \mu \mathrm{mol} \mathrm{L}^{-1}$. The remaining reagents used were the same as for Fe(II) analysis. Standards for standard addition calibrations were made using $30 \% \mathrm{H}_{2} \mathrm{O}_{2}$ obtained from Fluka (trace select). Signal values from depths with no presence of $\mathrm{H}_{2} \mathrm{O}_{2}$ were reproducibly lower than blanks from using aged MQ water (indicating 
presence $\mathrm{H}_{2} \mathrm{O}_{2}$ in the MQ water), and thus subtracted as blank values. Samples were only measured to the depth of the redox-cline since high $\mathrm{Fe}(\mathrm{II})$ concentrations interfere with the analysis (Yuan and Shiller, 1999).

\subsection{Organic iron(III) complexation}

Filtered seawater samples $(0.2 \mu \mathrm{m})$ from the GD samplings were analyzed for organic iron complexation using competitive ligand exchange cathodic stripping voltammetry (CLECSV). A Metrohm VA 993 Computrace equipped with a hanging mercury drop electrode, glassy carbon counter electrode, and $\mathrm{Ag} / \mathrm{AgCl}$ reference electrode was used. In general, iron was titrated by standard additions against a $10 \mu \mathrm{mol} \mathrm{L}^{-1}$ concentration of 2-(2-Thiazolylazo)-p-cresol (TAC) competing with the natural ligands for iron complexation in a EPPS buffered ( $\mathrm{pH}$ : 8.0) seawater sample based on Croot and Johansson (2000). A $1.79 \mu \mathrm{mol} \mathrm{L}^{-1}$ iron standard solution in $0.01 \mathrm{~mol} \mathrm{~L}^{-1}$ quartz distilled $\mathrm{HNO}_{3}$ was prepared from a $1000 \mathrm{mg} \mathrm{L}^{-1}$ stock (Titrisol, Merck) and a $0.01 \mathrm{~mol} \mathrm{~L}^{-1}$ solution of 2-(2-Thiazolylazo)-p-cresol (TAC, 97\%, Sigma Aldrich) was prepared in HPLC grade methanol. EPPS buffer (N-[2-hydroxyethyl]piperazine-N'[3-propanesulfonic acid], Sigma Ultra) was prepared in $1.0 \mathrm{~mol} \mathrm{~L}^{-1}$ ammonia solution $\left(\mathrm{NH}_{4} \mathrm{OH}, 25 \%\right.$, Fluka trace select) to a concentration of $1.0 \mathrm{~mol} \mathrm{~L}^{-1}$.

All analyses were performed at $20^{\circ} \mathrm{C}$ in a 10 step titration series on thawed aliquots of seawater samples that were frozen after collection to $-20^{\circ} \mathrm{C}$. Iron binding ligand concentrations and their conditional stability constants with respect to $\mathrm{Fe}^{\prime}\left(\log K_{\mathrm{Fe}^{\prime}}\right)$ were calculated from the titration curves using a single ligand model and applying a nonlinear fit to a Langmuir absorption isotherm (Croot and Johansson, 2000; Gerringa et al., 1995). The inorganic side reaction coefficient $\left(\alpha_{\mathrm{Fe}(\mathrm{TAC}) 2^{\prime}}\right)$ for the salinities of the samples was calculated based on published values at different salinities (Croot and Johansson, 2000; Croot et al., 2004a; Gerringa et al., 2007). Values of $\alpha_{\mathrm{Fe}(\mathrm{TAC}) 2^{\prime}}$ used were 2872, 2987, 2957, 2942, and 2851 for the salinities 7.12, 6.92, 6.97, 7.00, and 7.16 (in chronological order of the sampling occasions), respectively. Dissolved iron concentrations (ICP-MS measurements) are obtained from size fractionated iron analyses conducted in a parallel study (Gelting et al., 2009).

\subsection{DGT methodology}

Diffusive gradients in thin films (DGT) equipped with open pore (APA2) gels were used to sample the labile fraction of $\mathrm{Fe}$ (Davison and Zhang, 1994). Preparation of the gels followed procedures described earlier (Dahlqvist et al., 2002; Zhang and Davison, 1999). The labile Fe concentrations were calculated from the accumulated amounts in the DGTs according to Zhang and Davison (1995). The diffusion coefficient for $\mathrm{Fe}$ (received from DGT Research Ltd) was corrected for average temperatures measured in situ every five hours during the deployment period. All DGT units were assembled in a clean air trace metal laboratory and stored in clean plastic bags at $4^{\circ} \mathrm{C}$ before use. Blanks (not deployed in water) from each batch of assembled DGTs were measured and subtracted from the calculated labile $\mathrm{Fe}$ concentrations derived from the deployed DGTs. Labile concentrations are reported as the average result from duplicates. DGTs were deployed at 2 occasions, 24 May and 20 July, for 4 weeks. DGT units were deployed at $0.5,5,10,40$, and $120 \mathrm{~m}$ depth in a buoy system described by Forsberg et al. (2006). After collection, the DGT units were rinsed in MilliQ water, placed in clean, airtight plastic bags and stored at $4^{\circ} \mathrm{C}$ until analysis. The DGT devices were disassembled again in a clean air trace metal laboratory and the gels were eluted in $5 \mathrm{ml}$ of $5 \mathrm{~mol} \mathrm{~L}^{-1} \mathrm{qHNO}_{3}$ (single sub-boiling quartz distilled, AR grade nitric acid, Merck). Concentrations of Fe in DGT eluents and water samples were measured with an ICP-SFMS at Analytica $\mathrm{AB}$ in Luleå (Element, Thermo Fischer). For details about the instrument operation, see Rodushkin and Ruth (1997). Prior to analysis, water samples were diluted 4-fold with $0.16 \mathrm{~mol} \mathrm{~L}^{-1} \mathrm{qHNO}_{3}$ in MilliQ water.

\subsection{Analysis of associated parameters}

Seawater $\mathrm{pH}$ was determined using a temperature corrected $\mathrm{pH}$ electrode (Metrohm, $704 \mathrm{pH}$ meter), which was calibrated on the NBS/NIST scale against buffer solutions ( $\mathrm{pH} 6$ and 11, Merck CertiPUR) prior to each use. Second, the data were corrected to the seawater $\mathrm{pH}$ scale using the CO2SYS program (Lewis and Wallace, 1998), taking alkalinity and in situ temperature into account. We estimate the accuracy of this approach to be $0.05 \mathrm{pH}$ units. Salinity and temperature profiles were obtained from standard CTD casts (Landsort Deep: SST Memory probe by Sea \& Sun Technology $\mathrm{GmbH}$, Gotland Deep: Standard-Eco-Probe by Meerestechnik $\mathrm{GmbH}$ and ADM Standard Probe by ADM-Elektronik $\mathrm{GmbH}$ ), while alkalinity values are based on an alkalinitysalinity relationship for the Baltic Proper (Hjalmarsson et al., 2008, and S. Hjalmasson, personal communication, 2008). Macro-nutrients (total phosphate, $\mathrm{NO}_{3}^{-}$and $\mathrm{NO}_{2}^{-}$analyzed together, and $\mathrm{NH}_{4}^{+}$), as well as total hydrogen sulfide, oxygen and chlorophyll- $a$ (chl- $a$ ) were acquired from discrete samples, which at Landsort Deep were part of a water quality monitoring program. Samples for nutrients were filtered $(0.45 \mu \mathrm{m}$ Sarstedt Filtropur S membrane filter) into $12 \mathrm{~mL}$ plastic vials, and kept refrigerated until analysed within $24 \mathrm{~h}$ of sampling. Samples from the deep water were heat-treated $\left(60^{\circ} \mathrm{C}\right)$ for $1 \mathrm{~h}$ to kill remaining bacteria and prevent nitrification of ammonium. $\mathrm{PO}_{4}^{3-}, \mathrm{NH}_{4}^{+}$and $\mathrm{NO}_{2}^{-}+\mathrm{NO}_{3}^{-}$were determined by standard methods applied in segmented flow analysis (SFA, modified ALPKEM O. I. Analytical Flow Solution IV methods \# 319528, \# 319526, \# 319527, reporting limits: $\mathrm{PO}_{4}^{3-} 16 \mathrm{nmol} \mathrm{L}^{-1}, \mathrm{NH}_{4}^{+} 36 \mathrm{nmol} \mathrm{L}^{-1}$, and $\mathrm{NO}_{2}^{-}+\mathrm{NO}_{3}^{-}$ $14 \mathrm{nmol} \mathrm{L}^{-1}$ ). Oxygen was determined by the Winkler method (SS-EN 25 813) and $\mathrm{H}_{2} \mathrm{~S}$ according to Fonselius et 
al. (1999). Where no $\mathrm{H}_{2} \mathrm{~S}$ measurements were done, the presence of $\mathrm{H}_{2} \mathrm{~S}$ smell during tapping from the Niskin bottles was recorded when present. For chlorophyll $a$ determinations, $2 \mathrm{~L}$ of sea water were filtered on $47 \mathrm{~mm}$ Whatman GF/F filters, which were stored frozen at $-20^{\circ} \mathrm{C}$ and extracted by acetone before spectrophotometric measurements at $664 \mathrm{~nm}$ (SS 028146 ).

\subsection{Cyanobacterial counts}

On each occasion, three integrated phytoplankton samples $(0-20 \mathrm{~m})$ were collected with a $25 \mathrm{~m}$ long plastic tube (inner diameter $2.5 \mathrm{~cm}$ ). One end, equipped with a weight, was gently lowered to $20 \mathrm{~m}$ depth, after which the tube was closed at the upper end, retrieved, and emptied in a bucket. A $200 \mathrm{~mL}$ sub-sample, siphoned from the bucket while stirring, was preserved with $0.8 \mathrm{~mL}$ of Lugol's iodine ( $\mathrm{I}_{2}$ and $\mathrm{KI}$ ) solution supplemented with acetic acid. Filaments of heterocystous cyanobacteria were counted in units of $100 \mu \mathrm{m}$ in the whole bottom of a $25 \mathrm{~mL}$ settling chamber using a Leica inverted phase contrast microscope (10X objective and 150X total magnification). Cell volume was estimated by multiplying the counted units with species-specific mean cell volumes, determined from measurements. To convert to carbon, factors of 2.17, 14.4 and $2.11 \mu \mathrm{g} \mathrm{C} \mathrm{m}^{-1}$ filament were used for Aphanizomenon sp., Nodularia spumigena and Anabaena spp., respectively (Menden-Deuer and Lessard, 2000).

\subsection{Meteorology}

Meteorological data were obtained from the Swedish Meteorological and Hydrological Institute (SMHI) for the period 10 June-15 August 2007. Since no such data were available directly from the sampling stations, we utilized wind (speed and direction), precipitation, and global irradiation data from several locations in the closest possible vicinity (Hoburg and Visby on the island of Gotland; Östergarnsholm, a small island east of Gotland; Gotska Sandön, a small island north of Gotland; as well as Landsort A and Norrköping, which are on the Swedish mainland). Landsort A (58 $\left.75^{\prime} \mathrm{N}, 17^{\circ} 87^{\prime} \mathrm{E}\right)$ lays within relatively close proximity of the Landsort Deep station $\left(58^{\circ} 36^{\prime} \mathrm{N}, 18^{\circ} 4^{\prime} \mathrm{E}\right)$, and data from there are thus representative of the weather at Landsort Deep. In contrast, the other weather observatories used for Gotland Deep are more distanced from the sampling location and located on or near the island of Gotland (Gotska Sandön and Östergarnsholm being closest, Hoburg was further used for additional rain data) and the data from there are interpreted as being indicative for the conditions at this sampling station.

\section{Results}

\subsection{General water column patterns}

Surface temperatures increased from 15.4 to $19.7^{\circ} \mathrm{C}$ over the course of the summer at Gotland Deep (GD) and were 14.5 and $15.2^{\circ} \mathrm{C}$ during the two samplings at Landsort Deep (LD). Both locations, LD and GD, are characterized by a $\sim 60 \mathrm{~m}$ deep layer of low salinity $(S<7.5)$ surface water and an intermediate boundary water layer $(S=7.5-11,60-100 \mathrm{~m})$ overlaying more saline deep water $(S \sim 11$ at $\mathrm{LD}, S>12$ at GD). A differentiation between oxygenated surface water and oxygen-depleted deeper water, separated by a redoxcline at $\sim 80 \mathrm{~m}$, was present throughout most of the sampling period (Figs. 3a-d, 4a-d, 5a-d). A deeper, less abrupt, redoxtransition zone down to $100 \mathrm{~m}$ was observed at GD during 14 August (Fig. 5d). Accordingly, seawater $\mathrm{pH}$ decreased by more than one unit from 8.2 to 7.0 and from $8.4-8.7$ to 6.9-7.3 (also varying over time) over this depth range, at LD (Fig. 3a and b) and GD respectively (Figs. 4a and b, 5a and b). Likewise, oxygen is depleted and the anoxic water layer is characterized by $\mathrm{H}_{2} \mathrm{~S}$ presence and high $\mathrm{PO}_{4}$. The LD deep water is characterized by a peak of up to $14.9 \mu \mathrm{mol} \mathrm{L}^{-1} \mathrm{H}_{2} \mathrm{~S}$ and $\mathrm{PO}_{4}$ concentrations near $3.7 \mu \mathrm{mol} \mathrm{L}-1$ at $\sim 100-180 \mathrm{~m}$ depth, while GD anoxic water $\mathrm{PO}_{4}$ concentrations range between 4.0 and $5.4 \mu \mathrm{mol} \mathrm{L}^{-1}$ with $\mathrm{H}_{2} \mathrm{~S}$ presence being deepened to $170 \mathrm{~m}$ on 2 August (Figs. 3, 4, and 5c and d). Salinity and temperature indicate a mixed layer depth of 7 to $16 \mathrm{~m}$ at LD (Fig. 3a and b) and 16 to $21 \mathrm{~m}$ at GD (Fig. 4a and b, and Fig. 5a and b). Temperature data from 20 June at GD also indicate gradual re-stratification down to $10.5 \mathrm{~m}$ after previous mixing to $16 \mathrm{~m}$ depth (Fig. $4 \mathrm{a}$ ). In contrast, the 20 July and 2 August casts revealed recent mixing to $11.5 \mathrm{~m}$ and $21 \mathrm{~m}$, respectively (Figs. 4b, 5a). A second mixing event to $9.5 \mathrm{~m}$ depth as evident in the cast from 14 August (Fig. 5b) followed a deeper mixing to $21 \mathrm{~m}$ detected on $2 \mathrm{Au}-$ gust (Fig. 5a).

The temperature, salinity, and $\mathrm{PO}_{4}$ profiles of 4 July at $\mathrm{LD}$ show distinct perturbations of the water column between 40 and $60 \mathrm{~m}$ depth (Fig. 3a and c), which indicate mixing in of a different water mass with lower temperature and salinity. Further, a water mass intrusion with higher temperature was observed at $40-50 \mathrm{~m}$ depth at Gotland Deep on 20 July. This water mass also affected the $\mathrm{pH}$ profile at $40 \mathrm{~m}$ depth. The temperature signal persisted through 2 August, but was only reminiscent on 14 August (Figs. 4b, 5a and b).

\subsection{General meteorology}

The sampling period was characterized by very inconsistent weather. Periods of relatively strong winds (up to $15 \mathrm{~m} \mathrm{~s}^{-1}$ ) from variable directions, partly associated with heavy rain, frequently altered with calmer and sunnier conditions. We present rain data for the period of 10 days prior to each cruise (Fig. 6) for the following reasons. Rainfall has been shown 

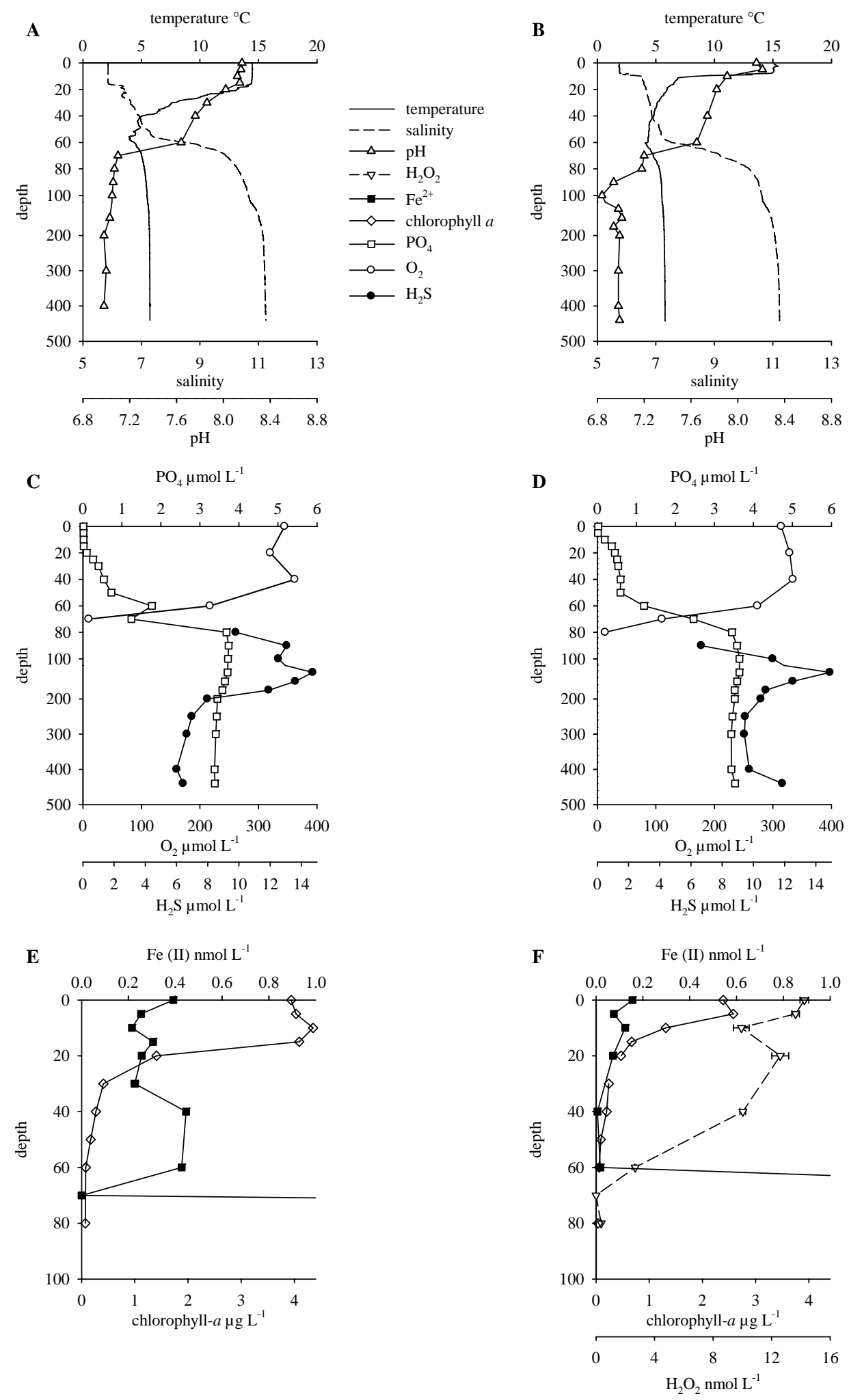

Fig. 3. Depth profiles of parameters measured throughout the water column at Landsort Deep. Note that the y-axis is stretched for better visibility of surface patterns between 0 and $100 \mathrm{~m}$ depth. (A) and (B) illustrate temperature in ${ }^{\circ} \mathrm{C}$, salinity (PSU), and $\mathrm{pH}$. (C) and (D) show dissolved oxygen $\left(\mathrm{O}_{2}\right)$, hydrogen sulfide $\left(\mathrm{H}_{2} \mathrm{~S}\right)$, and phosphate $\left(\mathrm{PO}_{4}\right)$. (E) and (F) show chlorophyll $-a$, iron(II), and hydrogen peroxide $\left(\mathrm{H}_{2} \mathrm{O}_{2}, \mathrm{~F}\right.$ only). Sampling dates were 4 July (A, C, and E) and 1 August 2007 (B, D, and F). 

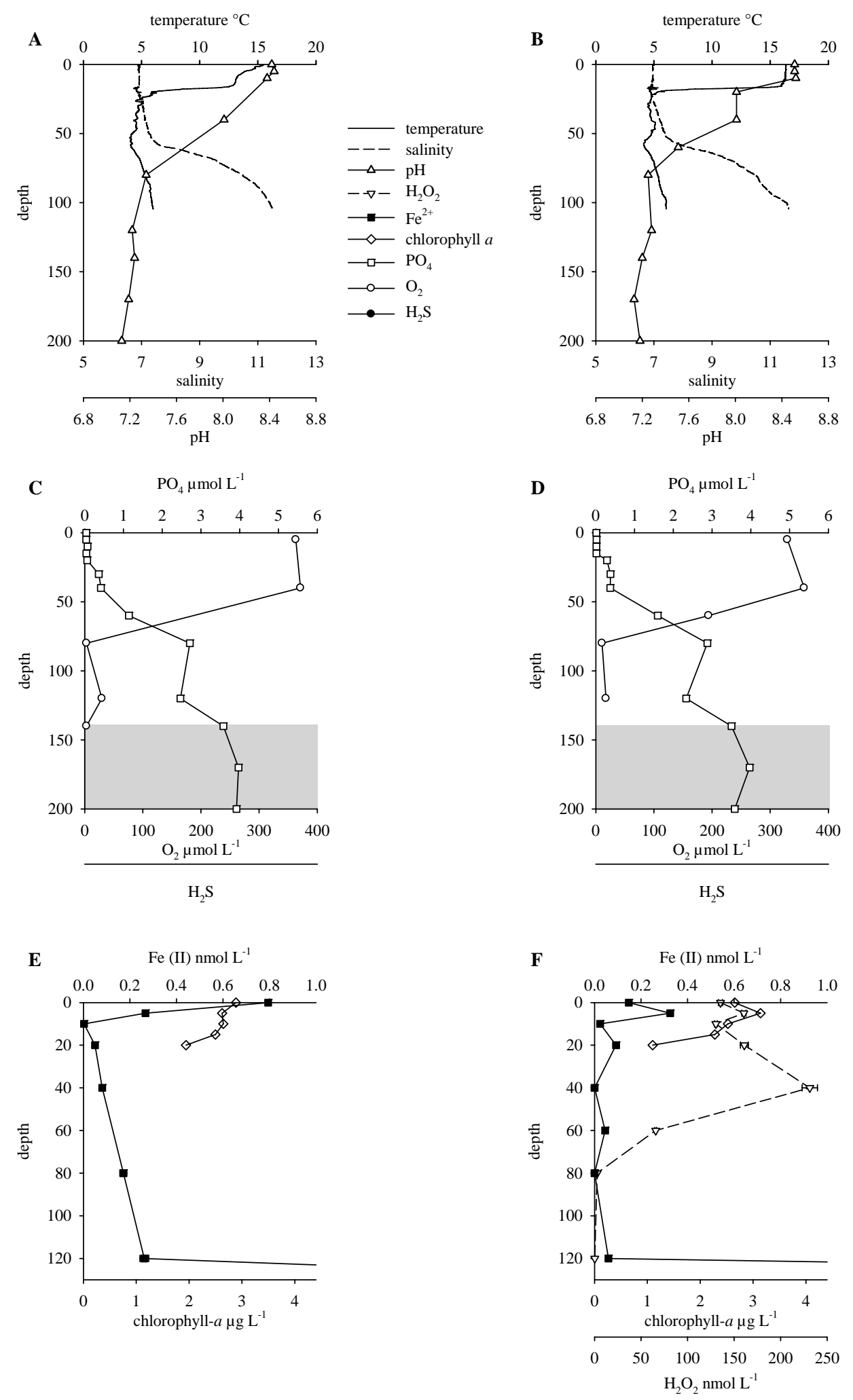

Fig. 4. Depth profiles of parameters measured throughout the water column at Gotland Deep. (A) and $(\mathbf{B})$ illustrate temperature in ${ }^{\circ} \mathrm{C}$, salinity (PSU), and pH. (C) and (D) show dissolved oxygen $\left(\mathrm{O}_{2}\right)$ and phosphate $\left(\mathrm{PO}_{4}\right)$. Hydrogen sulfide $\left(\mathrm{H}_{2} \mathrm{~S}\right)$ was not analytically measured and the grey zone indicates $\mathrm{H}_{2} \mathrm{~S}$ smell of the sampled water. (E) and (F) show chlorophyll-a, iron(II), and hydrogen peroxide $\left(\mathrm{H}_{2} \mathrm{O}_{2}, \mathrm{~F}\right.$ only). Sampling dates were 20 June (A, C, and E) and 20 July 2007 (B, D, and F). 

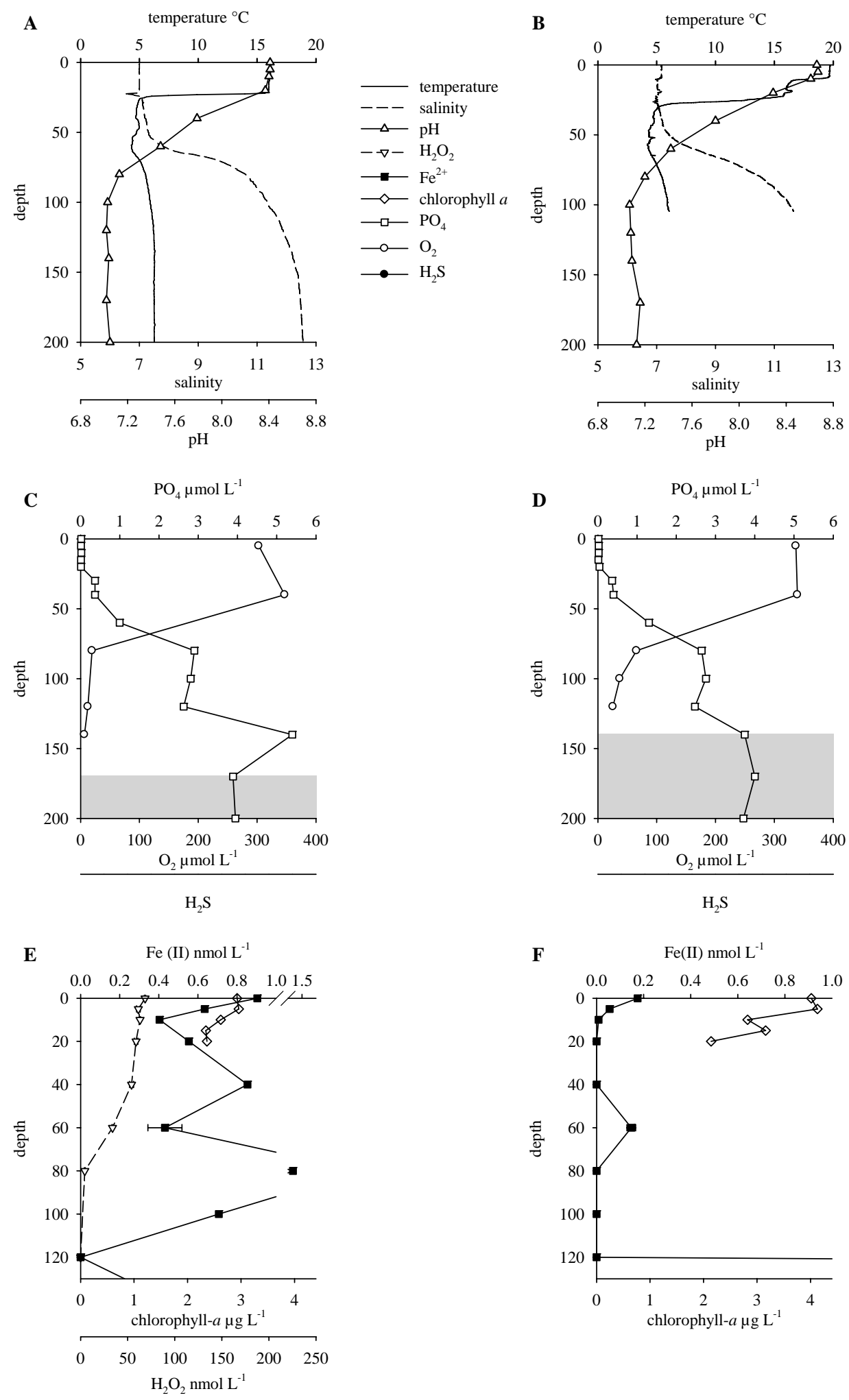

Fig. 5. Depth profiles of parameters measured throughout the water column at Gotland Deep. (A) and (B) illustrate temperature in ${ }^{\circ} \mathrm{C}$, salinity (PSU), and pH. (C) and (D) show dissolved oxygen $\left(\mathrm{O}_{2}\right)$ and phosphate $\left(\mathrm{PO}_{4}\right)$. Hydrogen sulfide $\left(\mathrm{H}_{2} \mathrm{~S}\right)$ was not analytically measured and the grey zone indicates $\mathrm{H}_{2} \mathrm{~S}$ smell of the sampled water. (E) and (F) show chlorophyll- $a$, iron(II), and hydrogen peroxide $\left(\mathrm{H}_{2} \mathrm{O}_{2}, \mathrm{E}\right.$ only). Sampling dates were 2 August (A, C, and E) and 14 August 2007 (B, D, and F). 
A

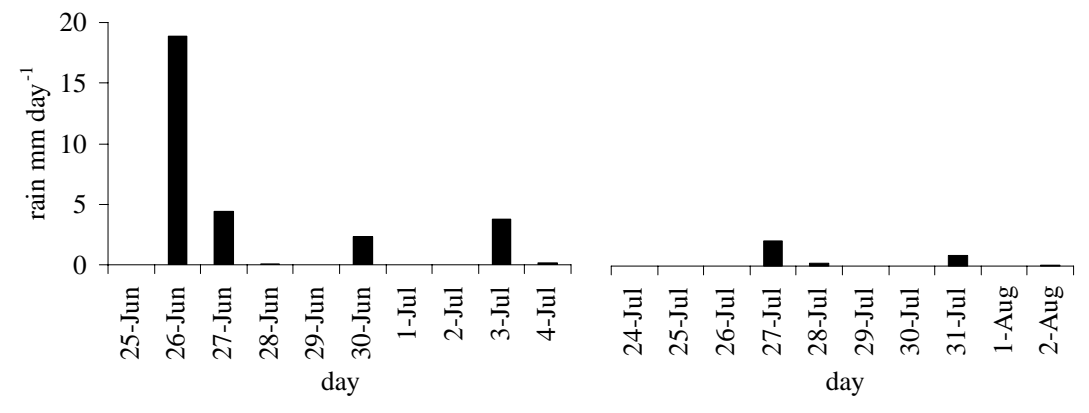

B

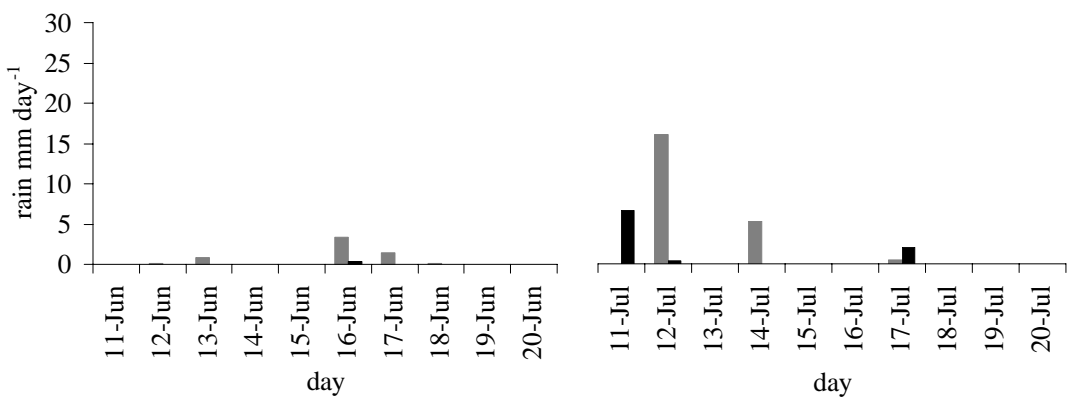

C
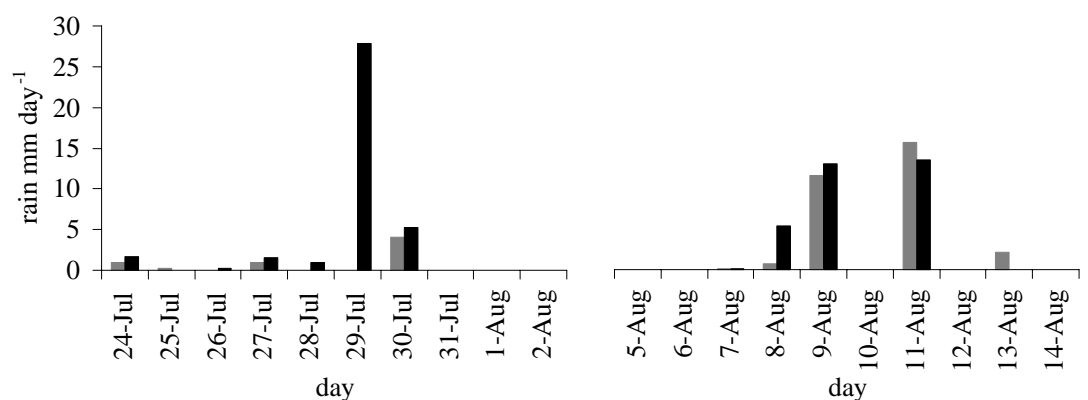

Fig. 6. (A) Rainfall at the meteorological station Landsort A. (B, C) Rainfall at the meteorological stations Gotska Sandön (grey) and Hoburg (black).

to deposit $\mathrm{H}_{2} \mathrm{O}_{2}, \mathrm{Fe}(\mathrm{II})$, and $\mathrm{Fe}(\mathrm{II})$ binding ligands into seawater. Hydrogen peroxide has a half life in the order of days in seawater between 14 and $20^{\circ} \mathrm{C}$. Rain deposited Fe(II) ligands may extend the half life of $\mathrm{Fe}(\mathrm{II})$ in oxygenated seawater considerably from minutes to hours at the temperature range observed (Kieber et al., 2001; Willey et al., 2008), while no published information on the persistence of such rain deposited $\mathrm{Fe}(\mathrm{II})$ ligands in seawater exists. Cruise dates that were preceded with stronger rainfall were 4 July (LD), 20 July (GD), as well as 2 and 15 August (GD) (Fig. 6).

At LD, wind speeds during the 4 July sampling were exceeding $10 \mathrm{~m} \mathrm{~s}^{-1}$ from east and south-east, enabling a long fetch across the Baltic Sea. In contrast, considerably weaker winds $\left(5-8 \mathrm{~m} \mathrm{~s}^{-1}\right)$ coming with less fetch from westerly directions were persisting before and during the second sampling (1 August) at this station and thus resulted in shallower mixing (Fig. 3a and b). Except for the 14 August sampling at Gotland Deep, all cruises were preceded with several days of wind speeds greater $10 \mathrm{~m} \mathrm{~s}^{-1}$, mostly from westerly direction. The Gotland Deep station is located in the middle of the Baltic Proper and thus enables a relatively long wind fetch for this enclosed sea. However, none of the wind driven mixing was deep enough to disturb the water column to the oxic-anoxic transition zone (Figs. 3a-d, 4a-d, and 5a-d). 
Table 1. Fe(II) oxidation rates and half lifes measured at Landsort Deep for the oxic and sub-oxic water layers compared with Fe(II) oxidation rates estimated based on Millero et al. (1987).

\begin{tabular}{|c|c|c|c|c|c|c|c|c|}
\hline \multirow[b]{2}{*}{$\begin{array}{l}\text { depth } \\
\mathrm{m}\end{array}$} & \multirow[b]{2}{*}{$\begin{array}{c}\log k_{O x} \\
\mathrm{~s}^{-1}\end{array}$} & \multirow[b]{2}{*}{$\begin{array}{l}t_{1 / 2} \\
\min \end{array}$} & \multicolumn{2}{|c|}{ measured } & \multirow[b]{2}{*}{$\begin{array}{c}\mathrm{pH}_{t} \\
\text { in situ }\end{array}$} & \multirow[b]{2}{*}{$\begin{array}{c}T \\
{ }^{\circ} \mathrm{C}\end{array}$} & \multicolumn{2}{|c|}{ predicted } \\
\hline & & & $\begin{array}{c}\mathrm{O}_{2} \\
\mu \mathrm{mol} \mathrm{L}^{-1}\end{array}$ & $\begin{array}{c}\mathrm{H}_{2} \mathrm{O}_{2} \\
\mathrm{nmol} \mathrm{L}\end{array}$ & & & $\underset{\min }{t_{1 / 2} \mathrm{O}_{2}}$ & $\begin{array}{c}t_{1 / 2} \mathrm{H}_{2} \mathrm{O}_{2} \\
\min \end{array}$ \\
\hline $4 \mathrm{Jul}$ & & & & & & & & \\
\hline 0 & -3.27 & 21.38 & 344.7 & & 8.18 & 14.48 & 1.03 & \\
\hline 5 & -3.09 & 14.28 & & & 8.17 & 14.49 & & \\
\hline 10 & -2.69 & 5.68 & & & 8.14 & 14.47 & & \\
\hline 15 & -2.60 & 4.63 & & & 8.16 & 14.43 & & \\
\hline 20 & -2.86 & 8.35 & 320.3 & & 8.04 & 13.16 & 2.87 & \\
\hline 30 & -2.38 & & & & 7.92 & 7.69 & & \\
\hline 40 & -2.50 & 2.75 & 362.2 & & 7.84 & 5.13 & 40.6 & \\
\hline 60 & -3.27 & 3.65 & 217.2 & & 7.73 & 4.37 & 145 & \\
\hline 70 & & & 10.3 & & 7.17 & 5.02 & 34999 & \\
\hline $1 \mathrm{Aug}$ & & & & & & & & \\
\hline 0 & -2.86 & 8.41 & 314.4 & 14.2 & 8.18 & 15.10 & 1.00 & 5.2 \\
\hline 5 & -2.79 & 7.09 & & 13.6 & 8.23 & 15.11 & & 4.8 \\
\hline 10 & -2.68 & 5.55 & & 9.9 & 7.96 & 8.46 & & 22.5 \\
\hline 20 & -2.67 & 5.36 & 328.8 & 12.6 & 7.88 & 5.95 & 30.7 & 27.2 \\
\hline 40 & & & 334.4 & 10.0 & 7.80 & 4.81 & 56.9 & 45.7 \\
\hline 60 & & & 273.8 & 2.7 & 7.74 & 4.29 & 109 & 212 \\
\hline 70 & & & 110.6 & 0.0 & 7.27 & 4.78 & 2174 & \\
\hline 80 & & & 13.4 & 0.35 & 7.23 & 5.30 & 19194 & 4796 \\
\hline
\end{tabular}

Table 2a. Fe(II) oxidation rates and half lifes measured at Gotland Deep for the oxic and sub-oxic water layers compared with Fe(II) oxidation rates estimated based on Millero et al. (1987).

\begin{tabular}{|c|c|c|c|c|c|c|c|c|}
\hline \multirow[b]{2}{*}{$\begin{array}{l}\text { depth } \\
\mathrm{m}\end{array}$} & \multirow[b]{2}{*}{$\begin{array}{c}\log k_{O x} \\
\mathrm{~s}^{-1}\end{array}$} & \multirow[b]{2}{*}{$\begin{array}{l}t_{1 / 2} \\
\min \end{array}$} & \multicolumn{2}{|c|}{ measured } & \multirow[b]{2}{*}{$\begin{array}{c}\mathrm{pH}_{t} \\
\text { in situ }\end{array}$} & \multirow[b]{2}{*}{$\begin{array}{c}T \\
{ }^{\circ} \mathrm{C}\end{array}$} & \multicolumn{2}{|c|}{ predicted } \\
\hline & & & $\begin{array}{c}\mathrm{O}_{2} \\
\mu \mathrm{mol} \mathrm{L}^{-1}\end{array}$ & $\begin{array}{c}\mathrm{H}_{2} \mathrm{O}_{2} \\
\mathrm{nmol} \mathrm{L}^{-1}\end{array}$ & & & $\begin{array}{c}t_{1 / 2} \mathrm{O}_{2} \\
\min \end{array}$ & $\begin{array}{c}t_{1 / 2} \mathrm{H}_{2} \mathrm{O}_{2} \\
\min \end{array}$ \\
\hline \multicolumn{9}{|l|}{20 Jun } \\
\hline 0 & -2.33 & 2.47 & & & 8.43 & 15.39 & & \\
\hline 5 & -2.43 & 3.12 & 363.1 & & 8.45 & 13.91 & 0.32 & \\
\hline 10 & & & & & 8.40 & 13.16 & & \\
\hline 20 & & & & & & 5.85 & & \\
\hline 40 & -2.73 & 6.18 & 371.3 & & 8.09 & 4.51 & 15.0 & \\
\hline 60 & & & & & & 4.12 & & \\
\hline 80 & & & 3.1 & & 7.40 & 5.32 & 37917 & \\
\hline 120 & & & 29.7 & & 7.26 & 6.20 & 6110 & \\
\hline \multicolumn{9}{|l|}{20 July } \\
\hline 0 & -2.31 & 2.38 & & 135.5 & 8.52 & 16.35 & & 0.23 \\
\hline 5 & -2.40 & 2.87 & 329.7 & 160.6 & 8.52 & 16.34 & 0.15 & 0.19 \\
\hline 10 & -2.44 & 3.15 & & 130.5 & 8.53 & 16.32 & & 0.23 \\
\hline 20 & -3.09 & 14.22 & & 161.1 & 8.10 & 5.32 & & 1.38 \\
\hline 40 & & & 358.4 & 231.4 & 8.08 & 4.78 & 15.2 & 1.1 \\
\hline 60 & & & 194.1 & 65.8 & 7.57 & 4.21 & 350.2 & 13.0 \\
\hline 80 & & & 10.9 & 2.84 & 7.30 & 5.31 & 17256 & 511 \\
\hline 120 & & & 17.5 & 0.34 & 7.37 & 6.20 & 6155 & 3244 \\
\hline
\end{tabular}


Table 2b. Fe(II) oxidation rates and half lifes measured at Gotland Deep for the oxic and sub-oxic water layers compared with Fe(II) oxidation rates estimated based on Millero et al. (1987).

\begin{tabular}{|c|c|c|c|c|c|c|c|c|}
\hline \multirow[b]{2}{*}{$\begin{array}{l}\text { depth } \\
\mathrm{m}\end{array}$} & \multirow[b]{2}{*}{$\begin{array}{c}\log k_{o x} \\
\mathrm{~s}^{-1}\end{array}$} & \multirow[b]{2}{*}{$\begin{array}{l}t_{1 / 2} \\
\min \end{array}$} & \multicolumn{2}{|c|}{ measured } & \multirow[b]{2}{*}{$\begin{array}{c}\mathrm{pH}_{t} \\
\text { in situ }\end{array}$} & \multirow[b]{2}{*}{$\begin{array}{c}T \\
{ }^{\circ} \mathrm{C}\end{array}$} & \multicolumn{2}{|c|}{ predicted } \\
\hline & & & $\begin{array}{c}\mathrm{O}_{2} \\
\mu \mathrm{mol} \mathrm{L}^{-1}\end{array}$ & $\begin{array}{c}\mathrm{H}_{2} \mathrm{O}_{2} \\
\mathrm{nmol} \mathrm{L}^{-1}\end{array}$ & & & $\begin{array}{c}t_{1 / 2} \mathrm{O}_{2} \\
\min \end{array}$ & $\begin{array}{c}t_{1 / 2} \mathrm{H}_{2} \mathrm{O}_{2} \\
\min \end{array}$ \\
\hline 2 Aug & & & & & & & & \\
\hline 0 & -2.50 & 3.69 & & 68.4 & 8.41 & 16.16 & & 0.58 \\
\hline 5 & -2.75 & 6.44 & 302.8 & 61.4 & 8.42 & 16.16 & 0.28 & 0.64 \\
\hline 10 & -2.75 & 6.48 & & 63.1 & 8.41 & 16.07 & & 0.64 \\
\hline 20 & -2.75 & 6.45 & & 59.0 & 8.38 & 15.98 & & 0.74 \\
\hline 40 & -2.83 & 7.84 & 346.9 & 54.2 & 7.85 & 4.73 & 44.6 & 7.62 \\
\hline 60 & & & & 34.0 & 7.53 & 4.35 & & 26.5 \\
\hline 80 & & & 19.7 & 4.48 & 7.18 & 5.53 & 15753 & 418.2 \\
\hline 100 & & & & $\mathrm{NaN}$ & 7.08 & 5.93 & & \\
\hline 120 & & & 12.5 & 0.00 & 7.07 & 6.20 & 35077 & - \\
\hline 140 & & & 6.6 & & 7.11 & 6.25 & 55572 & \\
\hline 14 Aug & & & & & & & & \\
\hline 0 & -2.56 & 4.19 & & & 8.67 & 19.72 & & \\
\hline 5 & -2.76 & 6.58 & 336.6 & & 8.68 & 19.68 & 0.04 & \\
\hline 10 & -2.72 & 6.02 & & & 8.64 & 18.29 & & \\
\hline 20 & & & & & 8.31 & 15.97 & & \\
\hline 40 & & & 339.1 & & 7.88 & 4.78 & 40.8 & \\
\hline 60 & & & & & 7.48 & 4.30 & & \\
\hline 80 & & & 65.6 & & 7.26 & 5.45 & 3326 & \\
\hline 100 & & & 37.2 & & 7.13 & 5.90 & 9599 & \\
\hline 120 & & & 25.6 & & 7.14 & 6.20 & 12624 & \\
\hline
\end{tabular}

\section{3 $\mathrm{Fe}(\mathrm{II})$}

\subsection{1 $\mathrm{Fe}(\mathrm{II})$ in the oxygenated water layer}

At both stations, $\mathrm{Fe}$ (II) concentrations differ greatly between the surface and the deeper water layers below the redox-cline. Surface values measured at LD range from $0-0.45 \mathrm{nmol} \mathrm{L}^{-1}$, while at $\mathrm{GD} F(\mathrm{FI})$ concentrations varied between 0 and $0.90 \mathrm{nmol} \mathrm{L}^{-1}$. On most occasions, Fe(II) concentrations are elevated in the upper meters of the water column and decrease with depth, suggesting photoreduction as a production mechanism (LD 1 August, GD 20 June, 2 and 14 August; Figs. 3f, 4f, 5e and f).

Oxidation rate calculations reveal short half life times $\left(t_{1 / 2}\right)$ of $\mathrm{Fe}(\mathrm{II})$ in surface water, which are mainly attributed to the relatively high $\mathrm{pH}$ in these estuarine waters. At GD at $5 \mathrm{~m}$ depth, $t_{1 / 2}=0.32,0.15,0.28$, and $0.04 \mathrm{~min}$ on $20 \mathrm{June}$, 20 July, 2 August, and 15 August, respectively. Oxidation rates were slower at $\mathrm{LD}$ resulting in $t_{1 / 2}=1.03$ and $1.00 \mathrm{~min}$ in surface water on 4 July and 1 August (Tables 1 and 2). In several cases $\mathrm{H}_{2} \mathrm{O}_{2}$ concentrations contribute significantly to the $\mathrm{Fe}$ (II) oxidation rates. $\mathrm{H}_{2} \mathrm{O}_{2}$ exceeds $200 \mathrm{nmol} \mathrm{L}^{-1}$ in one case at Gotland Deep (20 July $40 \mathrm{~m}$, Fig. 4f), resulting in $\mathrm{Fe}$ (II) half life times $\left(t_{1 / 2}\right)$ of $1.1 \mathrm{~min}$ versus $15.2 \mathrm{~min}$, when only the present oxygen concentration would be considered (no $\mathrm{Fe}(\mathrm{II})$ was detected at this depth on this station). Additionally, $\mathrm{O}_{2}$ is undersaturated in this case, which promotes the role of $\mathrm{H}_{2} \mathrm{O}_{2}$ as an oxidant for $\mathrm{Fe}(\mathrm{II})$. Oxygen undersaturation is a general pattern with increasing depths during our study in the Baltic Sea. Thus, also lower $\mathrm{H}_{2} \mathrm{O}_{2}$ concentrations can act as the main $\mathrm{Fe}(\mathrm{II})$ oxidant. This is the case at Landsort Deep on 1 August (20 and $40 \mathrm{~m}$ ), Gotland Deep 20 July $(60 \mathrm{~m})$, and Gotland Deep 2 August $(40 \mathrm{~m})$. Here the calculated $\mathrm{Fe}$ (II) half life times are 27.2 vs. 30.7 and 45.7 vs. 56.9 min, 13.0 vs. 350.2 , and 7.6 vs. 44.6 min for $\mathrm{H}_{2} \mathrm{O}_{2}$ and $\mathrm{O}_{2}$ respectively (Tables 1 and 2).

Further, $\mathrm{Fe}$ (II) measurements reveal that the actual Fe(II) oxidation rates are considerably slower than predicted in oxic surface water as shown by the decay function of the chemiluminescent signal (Tables 1 and 2). This is particularly prominent during the Landsort Deep sampling and results in a maximum Fe(II) half life of 21.4 min at the surface on 4 July as well as on 1 August (8.4 min).

\subsection{2 $\mathrm{Fe}(\mathrm{II})$ in subsurface waters and the oxic-anoxic transition zone}

Elevated $\mathrm{Fe}$ (II) levels were also detected at several tens of meters water depth, but clearly above the redox-cline, during nearly all cruises. Most prominently, this was the case on 4 
July at LD, where 0.45 and $0.43 \mathrm{nmol} \mathrm{L}^{-1} \mathrm{Fe}(\mathrm{II})$ were measured at 40 and $60 \mathrm{~m}$, respectively (Fig. 3e), but also on 2 August at GD $\left(0.85 \mathrm{nmol} \mathrm{L}^{-1}\right.$ at $40 \mathrm{~m}$ and $1.44 \mathrm{nmol} \mathrm{L}^{-1}$ at $80 \mathrm{~m}$, Fig. 5e) and 14 August at GD $\left(0.15 \mathrm{nmol} \mathrm{L}^{-1}\right.$ at $60 \mathrm{~m}$, Fig. 5f). While significant precipitation was recorded prior to these sampling dates (Fig. 6), these Fe(II) measurements are below the mixing depth and thus are unlikely a product of recent rain deposition. Further, Secchi depths ranged from 4.5-5.5 $\mathrm{m}$ throughout the samplings at both stations and thus also indicate insufficient light penetration for photochemical production of $\mathrm{Fe}(\mathrm{II})$ to these depths. At LD the $\mathrm{Fe}(\mathrm{II})$ peak between 40 and $60 \mathrm{~m}$ is paralleled by a temperature, salinity, and $\mathrm{PO}_{4}$ signal, which indicate either lateral transport of a different water mass or diapycnal mixing. This signal was only reminiscent on 1 August. However, in almost all cruises $\mathrm{Fe}(\mathrm{II})$ levels drop to zero at some point in the profile suggesting that such transport would not reach shallower water layers. A different pattern was only observed on 20 June at GD, where Fe(II) levels progressively increased with depth from $20 \mathrm{~m}$ on already (Fig. 4e). Further, at both stations $\mathrm{O}_{2}$ was present at depths greater $40 \mathrm{~m}$, albeit already at lower levels than in surface waters. $\mathrm{O}_{2}$ concentrations within this depth range indicate the transition from oxygenated surface water towards the oxic-anoxic interface (Figs. 4c and d, 5c and d). Below the redox-cline, low $\mathrm{pH}$ and increasing $\mathrm{H}_{2} \mathrm{~S}$ concentrations characterize a strongly reducing environment and $\mathrm{Fe}(\mathrm{II})$ concentrations rapidly increase by several orders of magnitude (Figs. 3, 4, 5), but we can not report on exact values as no calibrations were done in anoxic samples to correct for potential anoxia effects on the chemiluminescent reaction. Therefore, Fe(II) data are reported to a maximum depth of $100 \mathrm{~m}$ at LD and $120 \mathrm{~m}$ at GD throughout the manuscript.

\subsection{Hydrogen peroxide $\left(\mathrm{H}_{2} \mathrm{O}_{2}\right)$}

$\mathrm{H}_{2} \mathrm{O}_{2}$ profiles were measured on 1 August at LD, where maximum concentrations of $14.2 \mathrm{nmol} \mathrm{L}^{-1}$ at $0.5 \mathrm{~m}$ depth are generally up to an order of magnitude lower than concentrations at GD. A subsurface peak of $12.6 \mathrm{nmol} \mathrm{L}^{-1}$ was detected at $20 \mathrm{~m}$ depth and values decrease to 0 at $70 \mathrm{~m}$ depth. The measurement $0.35 \mathrm{nmol} \mathrm{L}^{-1} \mathrm{H}_{2} \mathrm{O}_{2}$ in the sub-oxic water $\left(13.4 \mu \mathrm{mol} \mathrm{O}_{2} \mathrm{~L}^{-1}\right)$ at $80 \mathrm{~m}$ depth may be interfered by high $\mathrm{Fe}$ (II) concentrations (Fig. 3f). At GD, two sampling occasions (20 July and 2 August) included $\mathrm{H}_{2} \mathrm{O}_{2}$ measurements and revealed differing results. Like at $\mathrm{LD}, \mathrm{H}_{2} \mathrm{O}_{2}$ levels on 2 August at GD decreased with depth as an apparent function of light penetration into the water column from $68.4 \mathrm{nmol} \mathrm{L}^{-1}$ at the surface to $4.5 \mathrm{nmol} \mathrm{L}^{-1}$ at $80 \mathrm{~m}$ depth. No $\mathrm{H}_{2} \mathrm{O}_{2}$ was detected at $120 \mathrm{~m}$ depth (Fig. 5e). In contrast to this profile, $\mathrm{H}_{2} \mathrm{O}_{2}$ measurements from the same station at the earlier 20 July sampling are considerably higher. In the upper $10 \mathrm{~m}$ of the water column values greater $130 \mathrm{nmol} \mathrm{L}^{-1}$ were measured and a peak of $160 \mathrm{nmol} \mathrm{L}^{-1}$ was detected a $5 \mathrm{~m}$. However, below $10 \mathrm{~m} \mathrm{H}_{2} \mathrm{O}_{2}$ increases again and peaks at $40 \mathrm{~m}$ depth $\left(231 \mathrm{nmol} \mathrm{L}^{-1}\right)$. Thereafter, values decrease gradually to $0.34 \mathrm{nmol} \mathrm{L}^{-1}$ at $120 \mathrm{~m}$ depth (Fig. 4f).

\subsection{Phytoplankton biomass}

Chlorophyll- $a$ (5 $\mathrm{m}$ depth) increased over the summer from $1.2 \mu \mathrm{g} \mathrm{L}^{-1}$ to $4.1 \mu \mathrm{g} \mathrm{L}^{-1}$, with a strong gain between $2 \mathrm{Au}$ gust and 14 August (Fig. 7a). The biomass of heterocystous cyanobacteria was initially dominated by Aphanizomenon sp. (Fig. 7b). This genus peaked on 20 June $\left(15 \mu \mathrm{g} \mathrm{CL}^{-1}\right)$ and thereafter its biomass progressively decreased again. In parallel, a decrease from 3.5 to 1 heterocyst per mm filament was observed in this genus (data not shown). The two other cyanobacteria genera that majorly accounted for the biomass were Nodularia and Anabena. Anabaena showed a similar development in biomass as Aphanizomenon, albeit peaking at much lower concentrations $\left(1.6 \mu \mathrm{g} \mathrm{CL}^{-1}\right)$. The Nodularia biomass reached its maximum 20 July $\left(17 \mu \mathrm{g} \mathrm{CL}^{-1}\right)$ and thereafter dropped by more than $50 \%$ (2 August) and slightly recovered to $11 \mu \mathrm{g}, \mathrm{CL}^{-1}$ on 14 August. The combined biomass of all three genera though was elevated during 20 June-20 July (25-28 $\mathrm{g} \mathrm{C} \mathrm{L} \mathrm{L}^{-1}$, Fig. 7b). The cyanobacterial biomass is integrated over the top $20 \mathrm{~m}$. Concentrations at $5 \mathrm{~m}$ depth may well be higher, especially when the mixed layer is shallow and particularly for Nodularia, which has high a buoyancy and usually accumulates in the surface (Walve and Larsson, 2007).

\subsection{Total and dissolved iron concentrations and organic iron(III) complexation at $5 \mathrm{~m}$ depth}

At GD, total iron concentrations increase from $10.6 \mathrm{nmol} \mathrm{L}^{-1}$ on 24 May to $12.9 \mathrm{nmol} \mathrm{L}^{-1}$ on 20 June. Levels are lowest in mid-June $\left(7.5 \mathrm{nmol} \mathrm{L}^{-1}\right)$ and increase again to $11.7 \mathrm{nmol} \mathrm{L}^{-1}$ on 14 August. Dissolved iron concentrations follow this trend during the first part of the summer with $2.8 \mathrm{nmol} \mathrm{L}^{-1}$ on 24 May and $7.0 \mathrm{nmol} \mathrm{L}^{-1}$ on 20 June. However, thereafter levels gradually decrease to $2.7 \mathrm{nmol} \mathrm{L}^{-1}$ on 14 August (Fig. 8a). Thus the source of total iron input in the end of the summer does not affect dissolved iron concentrations to the same extent as observed during the 20 June sampling (Fig. 8a). Iron binding ligands decline gradually from 10.1 to $3.4 \mathrm{nmol} \mathrm{L}^{-1}$ throughout the study. The surface seawater was deficient of free organic iron ligands on 20 June (by $1.4 \mathrm{nmol} \mathrm{L}^{-1}$ ), which was caused by high DFe levels at that date. Ligand concentrations were in excess of dissolved iron concentrations again for the rest of the summer (by $0.3-0.7 \mathrm{nmol} \mathrm{L}^{-1}$, Fig. 8b). Overall, the source of iron binding ligands is apparently decoupled from the source of total iron input. The conditional stability constant $\left(\log K_{\mathrm{Fe}^{\prime} \mathrm{L}}\right.$ ) increased from 11.4 to 12.9 from 24 May to 20 June and decreased again thereafter to 12.5 (20 July and 2 August) and 12.2 by 14 August. The concentrations of $\mathrm{Fe}^{\prime}$ range between 0.4 and $0.8 \mathrm{pmol} \mathrm{L}^{-1}$, being slightly elevated during the first part of the summer (Fig. 8b). 
A

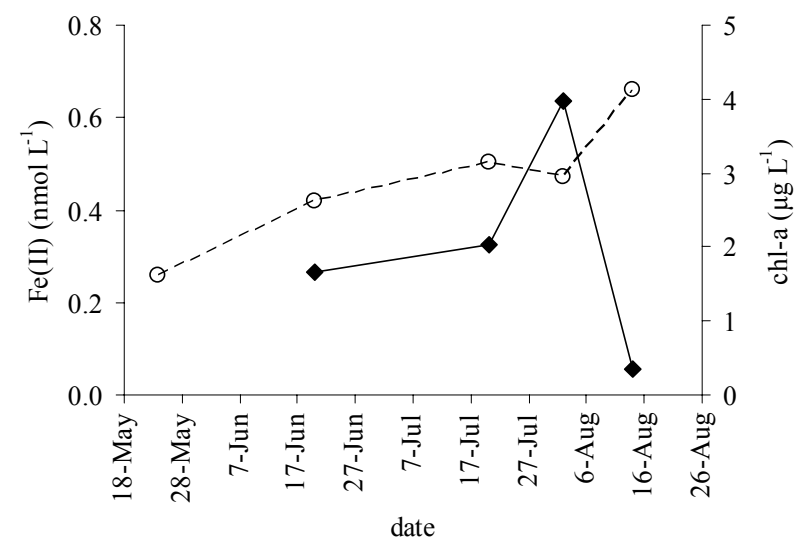

B

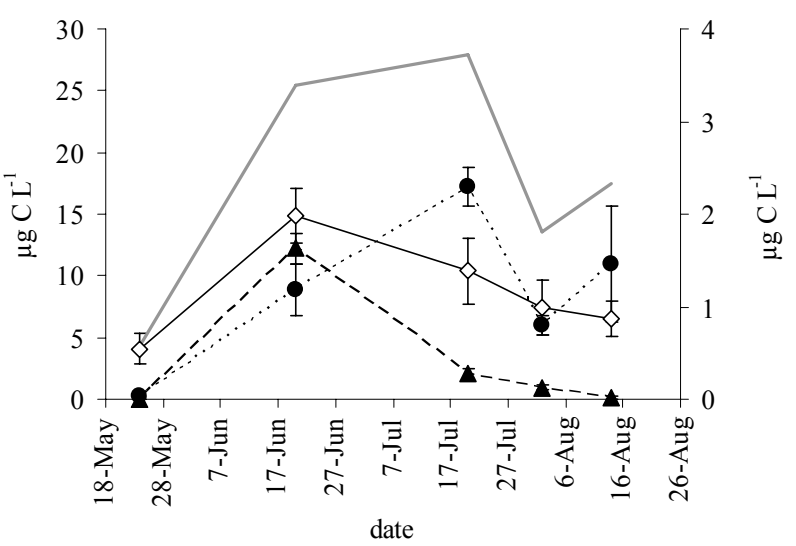

Fig. 7. (A) $\mathrm{Fe}$ (II) and chlorophyll- $a$ (chl- $a$ ) measurements at $5 \mathrm{~m}$ depth over the course of the study period at Gotland Deep. Fe(II) is depicted by solid diamonds and chl- $a$ is shown as open circles. (B) Development of heterocystous cyanobacteria in surface water $(0-$ $20 \mathrm{~m}$ depth) at Gotland Deep during the summer of 2007 expressed in $\mu \mathrm{g} \mathrm{CL}^{-1}$. Open diamonds indicate Aphanizomenon, solid circles show Nodularia, and solid triangles depict Anabaena (plotted on different scale on the right hand y-axis). The grey line shows the total biomass of heterocystous cyanobacteria. Error bars show standard deviations.

\subsection{DGT data}

DGT profiles resemble $\mathrm{Fe}(\mathrm{II})$ measurements in the oxygenated part of the water column. At the sea surface, DGT collected iron is elevated $\left(0.63\right.$ and $0.42 \mathrm{nmol} \mathrm{L}^{-1}$ during the periods 24 May-20 June and 20 July-14 August, respectively). In both profiles, the signal decreases to $0.17-$ $0.28 \mathrm{nmol} \mathrm{L}^{-1}$ at $5-10 \mathrm{~m}$ depth. In the first sampling interval, DGT measured iron progressively increases thereafter to $0.96 \mathrm{nmol} \mathrm{L}^{-1}$ at $80 \mathrm{~m}$ and then decreases to $0.74 \mathrm{nmol} \mathrm{L}^{-1}$ at $120 \mathrm{~m}$ depth. In contrast, the signal remains more constant to $40 \mathrm{~m}$ depth $(0.22 \mathrm{nM})$, and increases to $1.57 \mathrm{nmol} \mathrm{L}^{-1}$
A

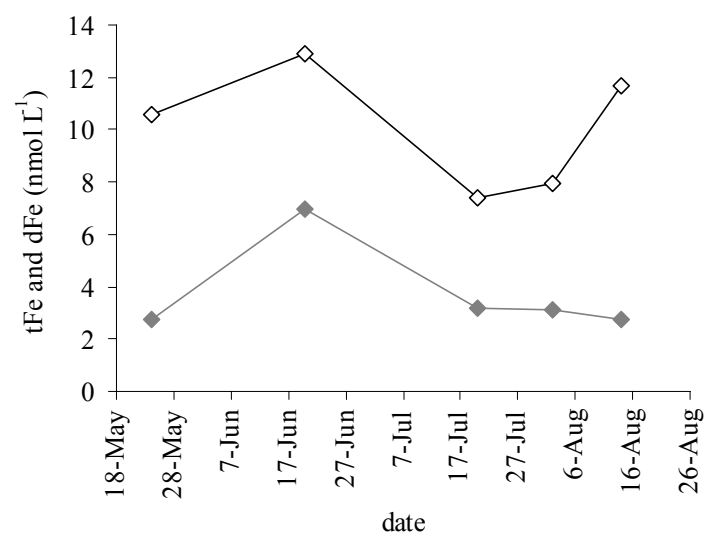

B

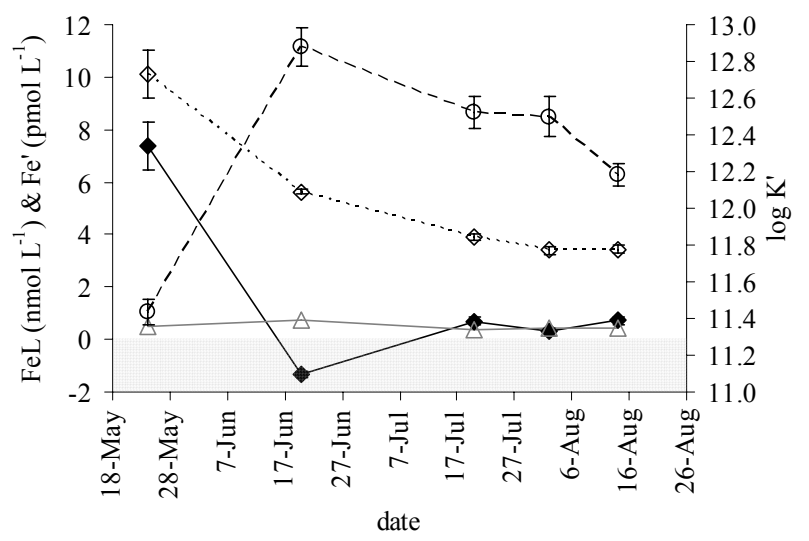

Fig. 8. (A) Development of total iron ( $\mathrm{tFe})$ and dissolved iron $(0.2 \mu \mathrm{m}$ filtered, $\mathrm{dFe})$ during the study period at $5 \mathrm{~m}$ depth at Gotland Deep. Open diamonds are total iron and solid diamonds show dissolved iron. (B) Organic complexation of the dissolved iron fraction and inorganic iron species ( $\left.\mathrm{Fe}^{\prime}\right)$ concentration during the different sampling occasions at Gotland Deep, $5 \mathrm{~m}$ depth. Open diamonds show the iron binding ligand concentrations; solid diamonds depict the concentration of excess ligands. The grey triangles show the concentration of $\mathrm{Fe}^{\prime}$. Circles indicate the conditional stability constant with respect to Fe' (plotted on the right hand y-axis). Error bars denote standard errors.

(closely matching $1.44 \mathrm{nmol} \mathrm{L}^{-1}$ in the $\mathrm{Fe}(\mathrm{II})$ profile from 2 August) at $80 \mathrm{~m}$ depth during the second time period. The signal though clearly exceeds FIA measured Fe(II) concentrations during this study with $63.4 \mathrm{nmol} \mathrm{L}^{-1}$ at $120 \mathrm{~m}$ depth (Fig. 9a and b).

\subsection{Macronutrients at $5 \mathrm{~m}$ depth}

At $\mathrm{GD}, \mathrm{PO}_{4}$ concentrations decrease from 179 to $12 \mathrm{nmol} \mathrm{L}^{-1}$ between 24 May and 2 August and slightly recover to $24 \mathrm{nmol} \mathrm{L}^{-1}$ on 14 August (Fig. 10a). The highest $\mathrm{dFe}$ to $\mathrm{PO}_{4}$ ratio $(0.26$, molar basis) was observed 

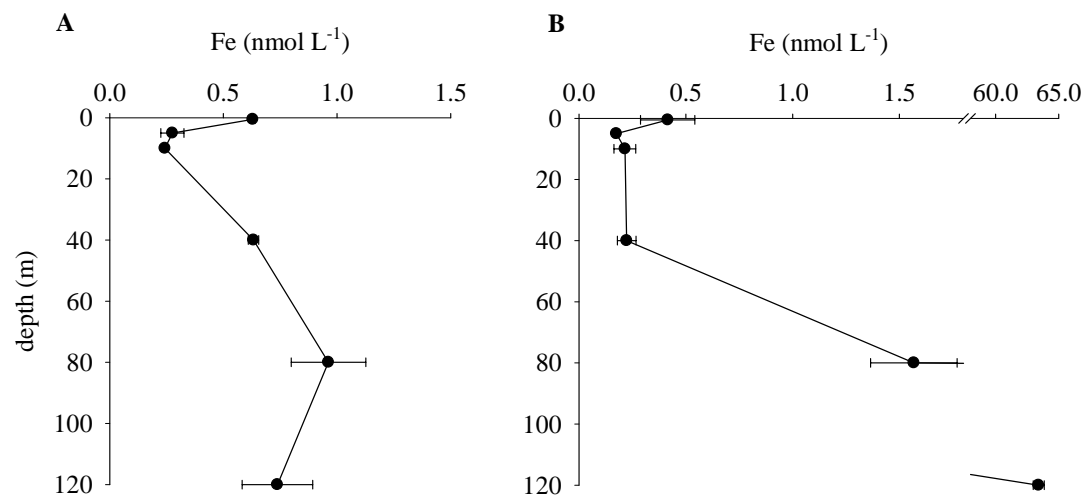

Fig. 9. Profile of DGT measured iron in the top $120 \mathrm{~m}$ water depth at Gotland Deep during the time period 24 May-20 June, 2007 (A) and 20 July-14 August, 2007 (B).

on 2 August (Fig. 10b). Combined $\mathrm{NO}_{3}+\mathrm{NO}_{2}$ analysis showed concentrations close to the detection limit on all occasions. Also $\mathrm{NH}_{4}$ concentrations were low $\left(<80 \mathrm{nmol} \mathrm{L}^{-1}\right)$ (Fig. 10a). Comparing combined dissolved inorganic nitrogen sources $\left(\mathrm{DIN}=\mathrm{NO}_{3}+\mathrm{NO}_{2}+\mathrm{NH}_{4}\right)$ with dissolved iron concentrations reveal a maximum $\mathrm{dFe}: \mathrm{DIN}$ molar ratio of 0.082 on 20 June (Fig. 10). DIN:DIP ratios at Gotland Deep were 0.5 on 25 May. As $\mathrm{PO}_{4}$ dropped, the ratio increased to 2.3 , and 3.3 on 20 June and 20 July respectively and further increased to 7.4 by 2 August, after which the ratio dropped again to 2.8. At the Landsort Deep, DIN:DIP stoichiometry was 7.4 and 6.0 during 4 July and 2 August, respectively.

\section{Discussion}

\section{1 $\mathrm{Fe}(\mathrm{II})$ in the oxygenated water layer}

Overall, this study aims to contribute to the understanding of iron cycling in the Baltic Sea. Specifically, it was the goal of our approach to evaluate the role of $\mathrm{Fe}$ and especially of $\mathrm{Fe}$ (II) for cyanobacterial bloom development in this brackish water ecosystem. In surface water, $\mathrm{Fe}$ (II) is largely produced photochemically (Kuma et al., 1995; Wells and Mayer, 1991; Croot et al., 2001) and concentrations are subject to diel cycling (Croot et al., 2008). Fe(II) can also be deposited during rain events (Kieber et al., 2001; Croot et al., 2005), and is a product of biological $\mathrm{Fe}$ (III) reduction mechanisms at phytoplankton cell surfaces (Shaked et al., 2004) including superoxide production (Kustka et al., 2005; Rose et al., 2005). However, it is not known if heterocystous cyanobacteria reduce $\mathrm{Fe}(\mathrm{III})$ at their cell surfaces.

$\mathrm{Fe}(\mathrm{II})$ in Baltic Sea surface waters apparently is persistent at relatively high standing stocks throughout extended periods of time. We observed $\mathrm{Fe}$ (II) concentrations accounting for up to $20 \%$ of the dissolved iron concentration at $5 \mathrm{~m}$ depth. $\mathrm{Fe}(\mathrm{II})$ thus contributed a significant fraction to the dissolved iron pool, and greatly enhanced the fraction of bioavailable iron. In an open ocean study, Roy et al. (2008) report $\mathrm{Fe}(\mathrm{II})$ concentrations in the HNLC western subarctic Pacific that account for up to $50 \%$ of the dissolved iron fraction and infer an important role of $\mathrm{Fe}(\mathrm{II})$ as a bioavailable source. Croot et al. $(2008,2001)$ show during the open ocean iron fertilization experiments EIFEX, SOFEX, and SOIREE that $\mathrm{Fe}(\mathrm{II})$ can contribute from $6-25 \%$ up to the major fraction of the dissolved Fe pool, stressing the importance of $\mathrm{Fe}$ (II) for Fe residence times in oceanic seawater. While the proportion $\mathrm{Fe}(\mathrm{II})$ contributes to the dissolved $\mathrm{Fe}$ pool in our estuarine water study is lower, the overall concentrations reach similar or several fold higher levels than in these open ocean waters.

Overall, the DGT and the $\mathrm{Fe}$ (II) profiles agree well on average concentrations, especially in the euphotic zone, which only reaches down to approximately $10 \mathrm{~m}$ based on Secchi depths of maximal $5.5 \mathrm{~m}$. Both DGT deployments revealed relatively similar concentrations of 0.52 $( \pm 0.15), 0.23( \pm 0.07)$, and $0.23( \pm 0.02) \mathrm{nmol} \mathrm{Fe} \mathrm{L}^{-1}$ at 0,5 , and $10 \mathrm{~m}$ depth, respectively. In comparison $\mathrm{Fe}(\mathrm{II})$ measurements show $0.50( \pm 0.40), 0.32( \pm 0.24)$, and 0.11 $( \pm 0.20) \mathrm{nmol} \mathrm{L}^{-1}$, at the same depths during the four measurement occasions and the larger variability in the data indicate the strong dependence of the Fe(II) signal on variable physical and chemical surface processes (Figs. 4e and f, 5e and $\mathrm{f}, 8$ ). Next to inorganic iron species (Fe'), which only exists at picomolar levels (Fig. 8b) and potentially also low molecular weight bound iron that is labile to DGT, Fe(II) ions are permeating through the DGT membrane and diffusive gel layer. However, other organically complexed iron may also enter the DGT sampler. The diffusion rate for a metal bound to fulvic acid though is 20 times slower than for the free metal ion (Scally et al., 2006). Our measurements propose that the main fraction of this DGT collected and presumably bioavailable iron is supplied in form of $\mathrm{Fe}(\mathrm{II})$. The disagreement of the two sampling techniques at $120 \mathrm{~m}$ (DGT profile 20 July-14 August, Figs. 4f, 5e and f, and 9b) indicates that a sporadic $\mathrm{Fe}(\mathrm{II})$ intrusion from anoxic deep water may have 
$\mathbf{A}$

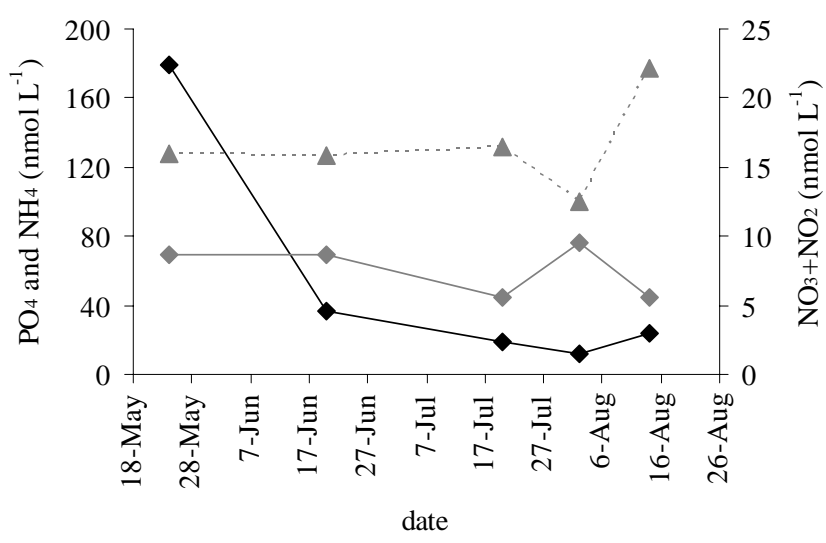

B

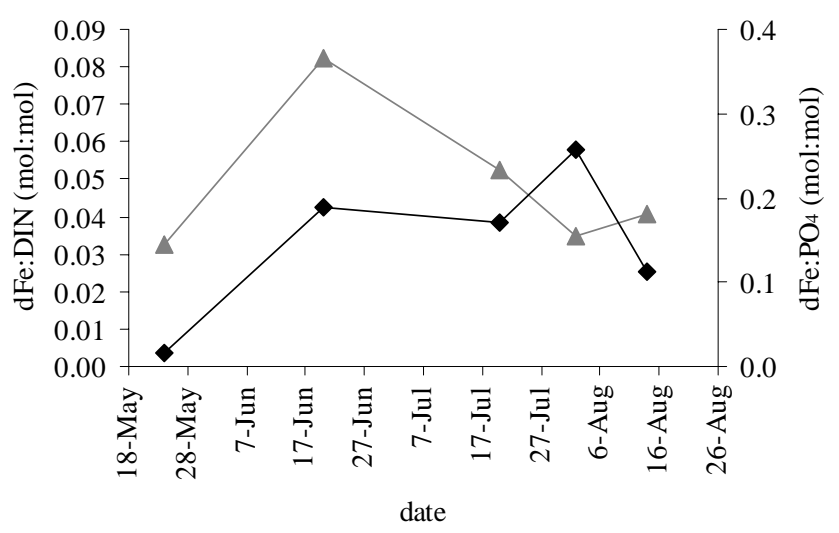

Fig. 10. (A) Development of macronutrients at $5 \mathrm{~m}$ water depth during the study at Gotland Deep. Phosphate $\left(\mathrm{PO}_{4}\right.$, black diamonds) and ammonia $\left(\mathrm{NH}_{4}\right.$, grey diamonds) are plotted on the left y-axis. $\mathrm{NO}_{3}$ and $\mathrm{NO}_{2}$ were measured together and are plotted on the right y-axis (grey triangle). (B) Macronutrient : dissolved iron stoichiometry at $5 \mathrm{~m}$ water depth at Gotland Deep. The ratio of dissolved inorganic nitrogen (DIN) : dissolved iron $(\mathrm{Fe})$ is shown by grey triangles (left y-axis). Phosphate $\left(\mathrm{PO}_{4}\right):$ Fe stoichiometry is depicted by black diamonds (right y-axis).

occurred during this time span and thus affected the DGT value, while the FIA measurements only reveal the momentary $\mathrm{Fe}(\mathrm{II})$ concentration.

\subsection{Factors controlling $\mathrm{Fe}(\mathrm{II})$ concentrations}

The general decrease of the Fe(II) signal with depth in the upper meters of the water column (Figs. $3 \mathrm{e}$ and $\mathrm{f}, 4 \mathrm{e}$ and $\mathrm{f}, 5 \mathrm{e}$ and $\mathrm{f}$ ) together with $\mathrm{Fe}(\mathrm{II})$ production during deck incubation in the light (data not shown) suggest that photochemical $\mathrm{Fe}(\mathrm{IIII})$ reduction is an important source of $\mathrm{Fe}(\mathrm{II})$ in this system. Coinciding $\mathrm{H}_{2} \mathrm{O}_{2}$ values with $\mathrm{Fe}$ (II) in the upper part of the water column indicate that both parameters are connected by photolysis of organic matter (Figs. 3f, 4f, 5e), albeit rainwater deposition can also be an important source (further discussed below). Comparing irradiation, dissolved oxygen, hydrogen peroxide, and $\mathrm{Fe}(\mathrm{II})$ concentrations over the course of the summer at Gotland Deep suggest that on 2 August the combination of the lowest $\mathrm{O}_{2}$ concentration during the summer $\left(303 \mu \mathrm{mol} \mathrm{L}^{-1}\right)$ and significantly less $\mathrm{H}_{2} \mathrm{O}_{2}\left(61 \mathrm{nmol} \mathrm{L}^{-1}\right.$ vs. $\left.161 \mathrm{nmol} \mathrm{L}^{-1}\right)$ than during the previous cruise (20 July) allowed for high $\mathrm{Fe}$ (II) levels at that time (Fig. 11). Theoretically, the oxygen present in surface water (5 $\mathrm{m}$ depth) still dominates $\mathrm{Fe}(\mathrm{II})$ oxidation rates and expected half-life's were rapid on these two dates (0.15$0.28 \mathrm{~min}$ ), while measured values were 2.9 and $6.4 \mathrm{~min}$ ( $\mathrm{Ta}-$ ble $2 \mathrm{a}$ and $\mathrm{b})$. Together with relatively low irradiation values during 2 August compared with the other cruises to this station this implies further sources of $\mathrm{Fe}$ (II) and/or Fe(II) maintenance mechanisms. Rainfall has been identified as a major source of $\mathrm{Fe}$ (II) to seawater (Kieber et al., 2001), Fe(II) binding ligands (Willey et al., 2008; Kieber et al., 2005), and $\mathrm{H}_{2} \mathrm{O}_{2}$ (e.g. Croot et al., 2004b; Willey et al., 2009).

Mixing of surface produced or rain water deposited $\mathrm{H}_{2} \mathrm{O}_{2}$ may be responsible for the presence at water depths below the euphotic zone. Hydrogen peroxide concentrations reported for rainwater range from $<10$ to $>80 \mu \mathrm{mol} \mathrm{kg}^{-1}$ and are affected by seasonality and solar irradiation (Croot et al., 2004b and references therein). Rain is frequent over the Baltic Sea during the Nordic summer and could thus contribute substantially to $\mathrm{H}_{2} \mathrm{O}_{2}$ in the water column. The study period was subject to frequent rain events and especially the cruise on 2 and 14 August (Gotland Deep) and 4 July (Landsort Deep) were preceded with periods of stronger rainfall (Fig. 6). Wind driven mixing though only penetrated the water column to depths of 16-21 m (Figs. $4 \mathrm{a}$ and $\mathrm{b}$ and $5 \mathrm{a}$ and b). Comparing $\mathrm{H}_{2} \mathrm{O}_{2}$ concentrations at Gotland Deep on 20 July (relatively high, Fig. 4f) and 2 August (relatively low, Fig. 5e) with rainfall data preceding these cruises (Fig. 6b and c) does not suggest rain as the only important contributor for $\mathrm{H}_{2} \mathrm{O}_{2}$ in surface waters. The dataset however does only allow for limited interpretation since rain data originate from distant locations of the sampling site and $\mathrm{H}_{2} \mathrm{O}_{2}$ data only cover two cruises. The rain data may partially explain the differences between the two stations in $\mathrm{H}_{2} \mathrm{O}_{2}$ concentrations since precipitation preceding the 2 August cruise to Landsort Deep (Figs. 3f and 6a) was considerably less than that recorded prior to the Gotland Deep cruises, where higher $\mathrm{H}_{2} \mathrm{O}_{2}$ values were detected (Figs. 4f, 5e, and $6 \mathrm{~b}$ ). Yet, in view of the shallow mixing depths, we infer that insitu production of $\mathrm{H}_{2} \mathrm{O}_{2}$ at these stations plays an important role in addition to rainfall. Hydrogen peroxide can also be a product of superoxide production on cell surfaces, cellular leakage processes and superoxide dismutase activity, and thus gets directly involved in cell surface iron reduction and uptake mechanisms (Pamatmat, 1997; Kustka et al., 2005). $\mathrm{H}_{2} \mathrm{O}_{2}$ concentrations $>200 \mathrm{nmol} \mathrm{L}^{-1}$ can affect $\mathrm{Fe}(\mathrm{II})$ oxidation rates above present $\mathrm{O}_{2}$ concentrations in surface seawater (Santana-Casiano et al., 2006). Such concentrations 


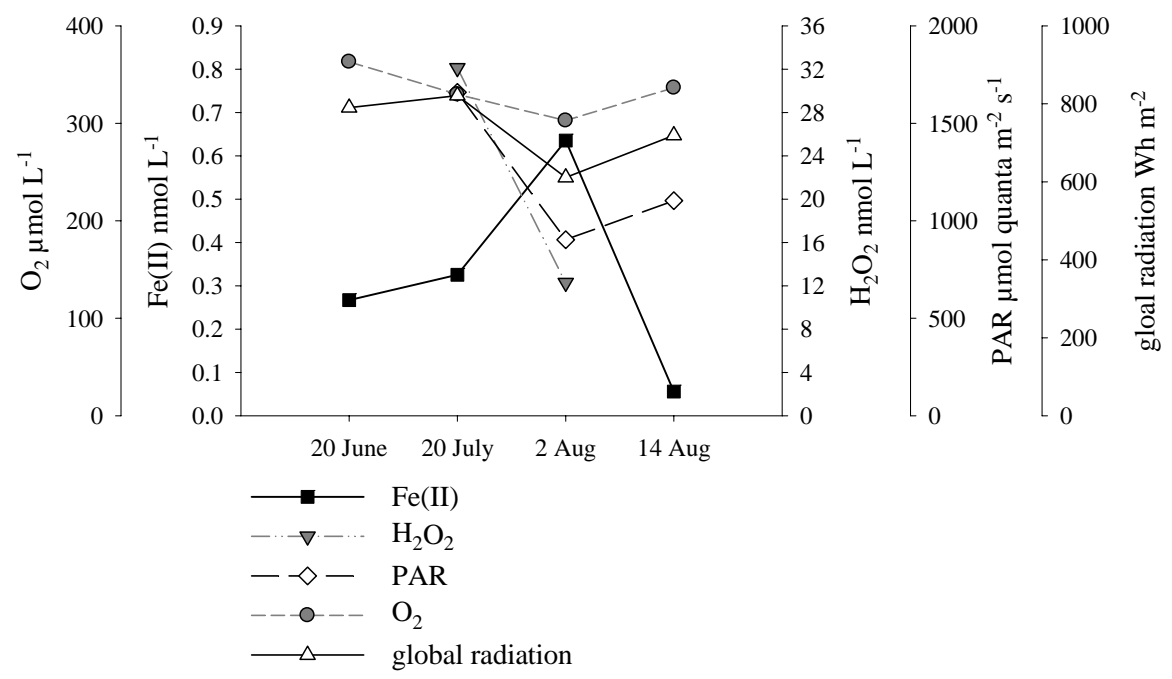

Fig. 11. Fe(II), surface irradiance (photosynthetic active radiation - PAR) measured on board the ship during the Fe(II) cast, global radiation measured at the SMHI station Visby on Gotland, hydrogen peroxide $\left(\mathrm{H}_{2} \mathrm{O}_{2}\right)$, and dissolved oxygen $\left(\mathrm{O}_{2}\right)$ from 20 June-14 August at Gotland Deep. $\mathrm{Fe}(\mathrm{II}), \mathrm{O}_{2}$ and $\mathrm{H}_{2} \mathrm{O}_{2}$ values refer to $5 \mathrm{~m}$ water depth.

however were only measured once (20 July, Fig. 4f) at $40 \mathrm{~m}$ depth in a Gotland Deep profile, where no detectable Fe(II) was present. However, if $\mathrm{O}_{2}$ is undersaturated, the role of $\mathrm{H}_{2} \mathrm{O}_{2}$ as an oxidant for $\mathrm{Fe}(\mathrm{II})$ is promoted. Oxygen undersaturation is a general pattern with increasing depths during our study in the Baltic Sea. Thus, also lower $\mathrm{H}_{2} \mathrm{O}_{2}$ concentrations can act as the main $\mathrm{Fe}(\mathrm{II})$ oxidant. This is the case at Landsort Deep on 1 August (20 and $40 \mathrm{~m}$ ), Gotland Deep 20 July $(60 \mathrm{~m})$, and Gotland Deep 2 August $(40 \mathrm{~m})$. Here the calculated $\mathrm{Fe}$ (II) half life times are 27.2 vs. 30.7 and 45.7 vs. $56.9 \mathrm{~min}, 13.0$ vs. 350 , and 7.6 vs. $44.6 \mathrm{~min}$ or $\mathrm{H}_{2} \mathrm{O}_{2}$ and $\mathrm{O}_{2}$, respectively (Figs. $3 \mathrm{~d}$ and f, $4 \mathrm{~d}$ and $\mathrm{f}$, and $5 \mathrm{c}$ and e). We unfortunately do not have $\mathrm{O}_{2}$ and $\mathrm{H}_{2} \mathrm{O}_{2}$ datasets that fully cover all depths on all sampling occasions, but the generally high DOM concentrations and rapid oxygen depletion with depth in Baltic Sea waters suggest that $\mathrm{H}_{2} \mathrm{O}_{2}$ control of $\mathrm{Fe}(\mathrm{II})$ oxidation rates may not be uncommon in subsurface waters, as further discussed later on.

While $\mathrm{Fe}(\mathrm{II})$ deposited during rain events prior to the cruises will have oxidized by the time of measurement, we infer that $\mathrm{Fe}$ (II) produced after this period may have been maintained at elevated levels by hampered Fe(II) oxidation rates due to organic $\mathrm{Fe}(\mathrm{II})$ complexation, as indicated in measured $\mathrm{Fe}(\mathrm{II})$ oxidation rates that are considerably slower than expected values in surface waters (Tables 1 and 2). Alternatively, superoxide, which may act as an iron oxidant or reductant, can be produced during photodegradation of phytoplankton exudates and thus may maintain elevated $\mathrm{Fe}$ (II) concentrations above predicted oxidation rates (Steigenberger et al., 2009; Croot et al., 2005; Millero and Sotolongo, 1989). Furthermore, the profile on 4 July (Landsort Deep, Fig. 3e) was measured at mid-night. While the Nordic summer at this latitude $\left(58^{\circ} 36^{\prime} \mathrm{N}\right)$ results in resid- ual light throughout most of the night (sunset 21:42 local time), the light intensity even at a few meters water depth and estimated $\mathrm{Fe}$ (II) oxidation rates not considering organic complexation would not allow for the detected Fe(II) concentrations to be present at mid-night. Here, Fe(II) halflife's expected for surface water at LD approximate $1 \mathrm{~min}$ and $2.9 \mathrm{~min}$ at $20 \mathrm{~m}$ on 4 July (Table 1). Nevertheless, 0.22 $0.39 \mathrm{nmol} \mathrm{L}^{-1} \mathrm{Fe}$ (II) were measured in the mixed layer and detected $\mathrm{Fe}$ (II) half lifes range between 4.6 and $21.4 \mathrm{~min}$ at this station (Table 1), which must be maintained by organic ligand binding, or a combination thereof with other insitu production mechanisms, such as cell surface reduction (O'Sullivan et al., 1991; Shaked et al., 2004; Kustka et al., 2005). The second Fe(II) maximum between $40-60 \mathrm{~m}$ depth is of different origin, but further discussion on this will be published separately (see also last paragraph of this section).

At Landsort Deep, measured oxidation rates increase with depth and are faster than predicted at depths were oxygen was present at high concentrations, but $\mathrm{pH}$ already dropped below 7.9 (Table 1). In contrast, oxidation rates decrease with depth at Gotland Deep, albeit also remaining slower than predicted in the high $\mathrm{pH}$ upper water layers. Measured oxidation rates were faster overall at Gotland Deep, resulting in Fe(II) half lifes of 2.4-4.2 min at the surface (Tables $2 \mathrm{a}$ and b). Hydrogen peroxide concentrations at Gotland Deep were considerably higher than at Landsort Deep and thus gain importance in $\mathrm{Fe}(\mathrm{II})$ oxidation. The trends with depth are an interrelation of temperature and $\mathrm{pH}$ with organic complexation effects on the oxidation rates by oxygen and hydrogen peroxide. While $\mathrm{pH}$ results in $\mathrm{Fe}$ (II) speciation shifts and slows oxidation rates overall, lower temperature promotes the importance of $\mathrm{H}_{2} \mathrm{O}_{2}$ over $\mathrm{O}_{2}$ for $\mathrm{Fe}$ (II) oxidation (Croot and Laan, 2002; Gonzalez-Davila et al., 2006). However, organic Fe(II) 
complexation appears to partially override these mechanisms in the surface water and thus measured $\mathrm{Fe}(\mathrm{II})$ oxidation rates only agree with predicted rates in subsurface waters between 20-40 m depth (20 July by $\mathrm{O}_{2}$ assuming $\mathrm{O}_{2}$ saturation ranges at levels similar to those of $5 \mathrm{~m}$ and $40 \mathrm{~m}$ depth, and $2 \mathrm{Au}-$ gust by $\mathrm{H}_{2} \mathrm{O}_{2}$, GD), where presumably less $\mathrm{Fe}$ (II) ligands are present. Additionally, competition by copper could slow $\mathrm{Fe}(\mathrm{II})$ oxidation rates, particularly when $\mathrm{Fe}(\mathrm{II})$ levels are low and $\mathrm{Cu}$ concentrations are relatively high (Gonzalez-Davila et al., 2006), which might contribute to the decreasing Fe(II) oxidation rates with depth in subsurface waters at Gotland Deep.

Copper concentrations in surface water of this region of the Baltic Sea generally account for up to $10 \mathrm{nmol} \mathrm{L}^{-1}$ (Pohl and Hennings, 1999, 2005). Roy et al. (2008) observed significant $\mathrm{Fe}$ (II) concentrations in the western subarctic Pacific and suggest that ligands containing amine or thiol functional groups may be responsible for Fe(II) complexation. This would be the case for copper specific ligands produced by phytoplankton to mitigate elevated copper stress (Dupont et al., 2004) and represents a second potential source for Fe(II) ligands next to rainfall. Copper complexation by thiol groups has been described for estuarine waters (Laglera and van den Berg, 2003) and was also observed in the Baltic Sea (B. Axelsson, personal communication, 2008). It is possible that copper ligand production has the side effect of Fe(II) complexation and thus maintains $\mathrm{Fe}(\mathrm{II})$ in seawater by slowing oxidation rates (Roy et al., 2008), therefore affecting the overall bioavailability of iron that otherwise is low due to the strong organic complexation and insufficient Fe' concentrations to fuel growth of large phytoplankton cells. Such a mechanism though remains to be validated for the Baltic Sea.

Alternatively, cyanobacteria aggregates could create low $\mathrm{pH}$ and low $\mathrm{O}_{2}$ microenvironments during darkness that greatly enhance iron solubility as suggested recently by Ploug (2008). Such mechanism could supplement the utilization of $\mathrm{Fe}$ (II) during daytime photoreduction and maybe even enhance the half life of Fe(II) at night. However, the frequent wind driven mixing observed during the 2007 summer season prevented surface accumulation and large aggregate formation of cyanobacteria as also indicated by satellite imagery (Hansson, 2007), which would be required to generate such microenvironments.

Finally, Fe(II) from the oxic-anoxic transition zone and in anoxic deep water could be a source to the euphotic zone. $\mathrm{Fe}(\mathrm{II})$ levels rapidly increase below the redox-cline (data not shown) and may reach levels of several hundred nanomoles (Strady et al., 2008). The prominent Fe(II) concentrations in the intermediate water layer (oxic-anoxic transition zone and above) at both stations are below the $1 \%$ light level $(\sim 10 \mathrm{~m}$ depth) and thus too deep for photoreduction or rain deposition as production pathways. Wind driven mixing of the water column during the study period though was not deep enough to reach the oxic-anoxic transition zone. The maximum mixing depth observed was $21 \mathrm{~m}$ at Gotland Deep as observed on 2 August 2008 (Fig. 5a). Thus either a local source, such as microbial iron reduction in sub-oxic waters as suggested by Moffett et al. (2007), isopycnal transport of $\mathrm{Fe}(\mathrm{II})$ rich water, or also diapycnal mixing and diffusion from the $\mathrm{Fe}$ (II) rich anoxic waters (as indicated by the progressive $\mathrm{Fe}(\mathrm{II})$ signal increase with depth below $20 \mathrm{~m}$ at Gotland Deep on 20 June, Fig. 4e) may be responsible for the Fe(II) signal within this depth range. Pohl et al. (2006) demonstrated the importance of small scale diapycnal mixing, independent of meteorological forcing, for dissolved trace metal fluxes across the halocline. Overall, the Fe(II) profiles suggest that mainly surface water processes are responsible for $\mathrm{Fe}(\mathrm{II})$ in the euphotic zone. However, particularly data from Gotland Deep on 20 June (Fig. 4e) illustrate how a combination of photoreduction in the euphotic zone and transport from deep water may operate and maintain $\mathrm{Fe}(\mathrm{II})$ throughout the water column, as also indicated by the gradual transition to high $\mathrm{PO}_{4}$ concentrations with increasing water depth across the redox-cline (Figs. 3, 4, and 5c and d).

\subsection{Significance of $\mathrm{Fe}(\mathrm{II})$ for cyanobacterial growth}

The cellular iron quota of Baltic Sea nitrogen fixing cyanobacteria is ca. $100 \mu \mathrm{mol} \mathrm{Fe}: \mathrm{mol} \mathrm{C}$ (data from Gotland Deep 2007, Walve unpublished) and thus results in a minimum cellular bound iron concentration of $0.23 \mathrm{nmol} \mathrm{L}^{-1}$ at the maximum cyanobacterial biomass of $2.32 \mu \mathrm{molCL}^{-1}$ (20 July). Using the cyanobacterial $\mathrm{C}$ fixation rate in (Walve and Larsson, 2007) and assuming that $50 \%$ goes into growth, the iron requirement of heterocystous cyanobacteria is ca. $1 \mathrm{nmol} \mathrm{L}^{-1}\left(0.017 \mathrm{nmol} \mathrm{L}^{-1}\right.$ day $\left.{ }^{-1}\right)$ for the two month growth period from 24 May to 20 July. Considering a 5-10 fold lower $\mathrm{Fe}$ demand for non-N-fixing phytoplankton than for $\mathrm{N}_{2}$ fixing cyanobacteria (Kustka et al., 2003a), and an approximate $\mathrm{C}$ fixation rate of $30 \mu \mathrm{g} \mathrm{CL}^{-1}$ day $^{-1}$ (Johansson et al., 2004) a rough estimation of the iron uptake during the same growth period ranges from 1.4$2.9 \mathrm{nmol} \mathrm{L}^{-1}\left(0.025-0.05 \mathrm{nmol} \mathrm{L}^{-1}\right.$ day $\left.{ }^{-1}\right)$. Half saturation constants with respect to inorganic iron reported for growth of the cyanobacteria Microcystis aeruginosa and Planktothrix agardhii were 0.14 and $0.31 \mathrm{nmol} \mathrm{L}^{-1}$, respectively (Nagai et al., 2007). Diatom species of the genus Thalassiosira have $\mathrm{Fe}$ ' half saturation constants to sustain their growth of $0.004-0.068 \mathrm{nmol} \mathrm{L}^{-1}$ (Sunda and Huntsman, 1995). Assuming similar requirements for the cyanobacteria and the eukaryotic phytoplankton present in the Baltic Sea, the standing stock of bioavailable iron of $0.25 \mathrm{nmol} \mathrm{L}^{-1}$ $0.5 \mathrm{nmol} \mathrm{L}^{-1}$ in the euphotic zone is sufficient to fuel primary production and nitrogen fixation in these waters.

Overall, nutrient stoichiometry (Fig. 10) suggest that classic N-limitation (DIN:DIP $\sim 0.5,24$ May) initiates the cyanobacterial bloom development. The ratio of dissolved iron concentrations to total phosphate and to dissolve inorganic nitrogen exceed those in oceanic regions by $2-3$ and 3-4 orders of magnitude, respectively (Franck et al., 2003). 
However, the relatively high iron concentrations compared to macronutrients may not be directly accessible to phytoplankton, if strong complexation limits Fe lability (Öztürk et al., 2002). Boyanapalli et al. (2007), using a luminescent bioreporter approach and water samples from the Gotland Deep station, demonstrate that only a proportion of the dissolved iron fraction is bioavailable and suggest potential iron limitation. Their study though is not carried out under natural daylight conditions and thus excludes Fe(II). Particularly in the context of iron limitation when the Fe(II) pool is excluded, our data suggest that $\mathrm{Fe}$ (II) plays a major role in iron acquisition by phytoplankton, namely diazotrophic cyanobacteria, in the Baltic Sea and may thus alleviate iron limitation as suggested for cyanobacterial bloom development and nitrogen fixation in the Baltic Sea (Stal et al., 1999; Schubert et al., 2007; Boyanapalli et al., 2007).

\subsection{Phytoplankton bloom dynamics and organic Fe(III)-complexation}

Organically complexed dissolved iron is progressively decreasing at Gotland Deep over the course of the study (Fig. 8b). Fe(II) concentrations do not correlate with Fe(III) ligand concentrations, indicating that this substratum for photoreduction of iron apparently is present at sufficient levels or that at least a fraction of $\mathrm{Fe}(\mathrm{II})$ present in surface water is also contributed from other sources such as reduction from colloidal iron, rainfall, or deep water (as discussed above). The decrease of iron binding ligands parallels the decrease in $\mathrm{PO}_{4}$ and is inversely related to the chlorophyll- $a$ increase at $5 \mathrm{~m}$ water depth (Figs. 7a, 8b, and 10a). The latter two are typical for seasonal nutrient draw down with cyanobacterial bloom development in the Baltic Sea, where DIN sources had already been depleted by eukaryotic phytoplankton (Stal et al., 2003), as shown by low DIN concentrations (Fig. 10a). Biological uptake of organically complexed iron may be partially responsible for the decrease in iron binding ligands, albeit it is also possible that dissimilatory photoreduction of dissolved organic matter simply parallels phytoplankton bloom development and nutrient uptake during the high solar irradiation summer months. Moreover, the conditional stability constant of iron binding ligands $\left(\log K_{\mathrm{Fe}^{\prime} \mathrm{L}}=11.4\right.$ in the beginning of the study) increases during the summer to $\log K_{\mathrm{Fe}^{\prime} \mathrm{L}}=12.9$ and remains elevated at $\sim 12.5$ until early August (Fig. 8b) and thus indicates a shift in the composition of the organic matter acting as iron binding ligands. During the June and July cruises, the total biomass of heterocystous cyanobacteria was elevated as well. This parallel trend suggests that the iron ligand characteristics are connected to the phytoplankton bloom dynamics and that at least a proportion of the ligands present may be biologically produced or a byproduct of bloom development, such as transparent exopolymer particles (TEP) and surfactants (Croot et al., 2007; Ingri et al., 2004). After this, $\log K_{\mathrm{Fe}^{\prime} \mathrm{L}}$ slightly drops to 12.2 (14 August) and the same time chlorophyll- $a$ and iron ligand concentrations increase again. Further, the chlorophyll- $a$ and Nodularia spumigena biomass increase in the late summer is preceded by a peak in $\mathrm{Fe}$ (II) concentration and a small peak in $\mathrm{NH}_{4}$ (Figs. 7a and b, 10a), which could have been a product of DON photochemical mineralization (Vähätalo and Zepp, 2005) exceeding present ammonium uptake and together with a shallower thermocline and $\mathrm{N}$ inputs from rain and senescent cyanobacteria, may have induced a second growth period for phytoplankton.

Aphanizomenon sp., Nodularia spumigena, and Anabaena sp. are the main representative species identified of the filamentous cyanobacteria that peak in abundance and biomass during the earlier part of the summer ( 25 and $28 \mu \mathrm{g} \mathrm{CL}^{-1}$ on 20 June and 20 July, respectively). Anabaena sp. has been described to produce the siderophore schizokinen in response to iron stress (Clarke et al., 1987) as well as the cyanotoxin microcystein that also has siderophore type characteristics (Kaebernick and Neilan, 2006; Utkilen and Gjolme, 1995; Humble et al., 1997). Further, Stolte et al. (2006) observed that cyanotoxin production by Nodularia spumigena increases during incubations with combined additions of DOM and Fe. The toxin production of Nodularia spumigena could be a response to increase metal bioavailability in media with strong DOM-metal complexation, where the dissolved iron concentrations are high, but the actual concentration of the bioavailable inorganic iron species ( $\left.\mathrm{Fe}^{\prime}\right)$ is low, which also is the case here (Fig. 8b). Moreover, the pico-cyanobacteria such as Synechococcus sp. were not assessed in our study, but can contribute up to $80 \%$ of the cyanobacterial biomass (Stal et al., 2003). Synechococcus sp. is ubiquitous marine cyanobacterium and known as a producer of strong iron siderophores (Wilhelm et al., 1996) that can be photolabile (Barbeau et al., 2003). Cabaj and Kosakowska $(2005,2009)$ further demonstrated siderophore production of Baltic Sea heterotrophic bacteria and diatoms. In the open ocean siderophores however were shown to only contribute $0.2-4.6 \%$ to the dissolved iron complexation capacity (Mawji et al., 2008). The contribution of siderophores may be higher here, but the main proportion of iron complexing substances in coastal seawater, and especially in the Baltic Sea, would be dissolved organic matter (DOM) such as humic and fulvic acids (Hagström et al., 2001; Öztürk et al., 2002; Rose and Waite, 2003; Bergström et al., 2001), which can be present in truly dissolved or colloidal form (Hassellöv, 2005; Wells, 1998). DOM in the Baltic Sea is largely of terrestrial origin and subject to seasonality (Stedmon et al., 2007; Pempkowiak, 1983) and was shown to complex and transport trace metals into this land locked sea (Pettersson et al., 1997a; Pempkowiak, 1991). Photodegradation gradually decreases the DOM concentrations over the summer season (Skoog et al., 1996; Pettersson et al., 1997b; Vähätalo and Zepp, 2005). Here iron binding ligands were diminished into a state of ligand deficiency with regard to dissolved iron concentrations in the early summer (20 June). Fe ligand concentrations are in excess again of DFe 
concentrations for the remaining study period (Fig. 8b). During the summer the contribution of locally produced bloom byproducts such as TEP and surfactants may gain importance with the decrease of total ligand concentrations. We suggest that local production of iron chelators may hence counteract the overall loss of humic substances and colloidal iron by processes such as photodegradation and export over the summer. What percentage of the total iron binding ligands detected here is supplied by Anabaena sp., Nodularia spumigena, or also Synechococcus sp. remains unclear, but given the shift in the conditional stability constants paralleling the cyanobacterial bloom development during the summer it seems plausible that at least a fraction can be attributed to cyanobacterial toxin and thus ligand production, next to bloom byproducts (TEP, surfactants). Stolte et al. (2006) conclude that iron concentrations in the Baltic Sea are sufficient for cyanobacterial growth, but that species composition could be affected by species specific iron acquisition strategies. Our observations of abundance and successive growth of Aphanizomenon sp., Nodularia spumigena, and Anabaena sp. at Gotland Deep during the 2007 summer match this hypothesis, considering that the latter two are toxin and iron ligand producers.

As aforementioned, the decrease of iron binding ligands in the surface waters during the summer will also be driven by iron utilization from iron-ligand complexes, which can include iron-ligand uptake or loss of ligands after reduction of the iron-ligand complex at the cell surface (Morel et al., 2008; Shaked et al., 2005). Fe(III) organic ligands can be photostable or photolabile. Ligand-metal charge transfer during ligand photoreduction and successive release of Fe(II) from the organic complex during photoreduction can further result in ligand destruction by irradiance, which results in $\mathrm{H}_{2} \mathrm{O}_{2}$ production (Rijkenberg et al., 2006a, 2006b; Morel et al., 2008; Maldonado et al., 2005; Barbeau, 2006; Barbeau et al., 2001). The photochemistry of this micronutrient further also counteracts losses by colloid and particle formation of bioavailable iron in the LMW fraction during bloom development, given that such a mechanism as identified for other trace metals also affects iron biogeochemistry in the Baltic Sea (Ingri et al., 2004). Despite the increase in total iron towards the end of the summer the dissolved iron concentrations in our study progressively decrease (Fig. 8a). Particulate iron may in part be composed of iron taken up into phytoplankton cells, of which in this ecosystem a considerable fraction was initially supplied in form of $\mathrm{Fe}(\mathrm{II})$. Thus, biogenic particles after phytoplankton blooms may be the major sink of iron, as also suggested by Gelting et al. (2009).

\section{Conclusions}

We conclude that the Baltic Proper is a stoichiometrically low nutrient - high iron system and that a large fraction of the bioavailable iron is supplied via Fe(II). Further, we identify three distinct sections in the water column, which each show individual characteristics of $\mathrm{Fe}$ (II) cycling. A - The fully oxygenated euphotic zone where photoreduction of Fe(III) is an important source of $\mathrm{Fe}(\mathrm{II})$. The actual contribution of rainwater to $\mathrm{Fe}(\mathrm{II})$ concentrations remains to be demonstrated, but standing stocks of Fe(II) in surface water apparently are maintained to some extent by rain deposited Fe(II) ligands. It is unclear though, what the production and turnover rates of $\mathrm{Fe}(\mathrm{II})$ are, which would be crucial to fully understand the role of $\mathrm{Fe}(\mathrm{II})$ in the bioavailable Fe pool. B - The oxic-anoxic transition zone above the pycnocline features also presence of Fe(II). Here light levels are insufficient for photochemical processes to operate. Other mechanisms, such as lateral transport of water masses, local production, or input of $\mathrm{Fe}$ (II) from anoxic deep waters may elevate $\mathrm{Fe}(\mathrm{II})$ concentrations in this sub-oxic part of the water column. C - In anoxic waters thermodynamics favor all iron in anoxic water to be reduced to $\mathrm{Fe}(\mathrm{II})$. Wind driven mixing does not penetrate down to anoxic waters during summer time, but Fe(II) from deep water may be a temporal source to overlaying water layers due to diffusion or after diapycnal mixing events.

Acknowledgements. The authors are very grateful to $\mathrm{Mu}-$ rat V. Ardelan for lending his FIA system. K. N'dungu, H. Paulava, and R. Rentz helped at sea. Special thanks to P. Croot and C. Neill for the use of their FIA data acquisition program. Thanks also to the staff at the Department of Systems Ecology, Stockholm University, for analyzing nitrogen, phosphorus, chlorophyll, oxygen, and hydrogen sulfide. Meteorological data were provided by the Swedish Meteorological and Hydrological Institute (SMHI) and we acknowledge the help of E.-M. Wingqvist. This work was supported by Formas Grant No: 217-2005-1879 awarded to J. Ingri, M. Hassellöv, et al. E. Breitbarth further acknowledges financial support from Kempestiftelserna, the Gothenburg Marine Research Center, and the German Research Foundation (DFG, BR 3794). L. Hoffmann was supported by a DAAD fellowship and by the DFG (DFG, HO 4217). Stockholm Marine Research Center is thanked for subsidized access to the research vessel Fyrbyggaren. The manuscript was greatly improved by the in-depth reviews from P. L. Croot and an anonymous reviewer.

Edited by: K. Hunter

\section{References}

Anderson, M. A. and Morel, F. M. M.: The Influence of Aqueous Iron Chemistry on the Uptake of Iron by the Coastal Diatom Thalassiosira weissflogii, Limnol. Oceanogr., 27, 789-813, 1982.

Barbeau, K., Moffett, J. W., Caron, D. A., Croot, P. L., and Erdner, D. L.: Role of protozoan grazing in relieving iron limitation of phytoplankton, Nature, 380, 61-64, 1996.

Barbeau, K., Rue, E. L., Bruland, K. W., and Butler, A.: Photochemical cycling of iron in the surface ocean mediated by microbial iron(III)-binding ligands, Nature, 413, 409-413, 2001.

Barbeau, K., Rue, E. L., Trick, C. G., Bruland, K. T., and Butler, A.: Photochemical reactivity of siderophores produced by marine heterotrophic bacteria and cyanobacteria based on character- 
istic Fe(III) binding groups, Limnol. Oceanogr., 48, 1069-1078, 2003.

Barbeau, K.: Photochemistry of organic iron(III) complexing ligands in oceanic systems, Photochem. Photobiol., 82, 1505-1516, doi:10.1562/2006-06-16-ir-935, 2006.

Bergström, S., Alexandersson, H., Carlsson, B., Josefsson, W., Karlsson, K.-G., and Westring, G.: Climate and hydrology of the Baltic Basin, in: Ecol. Stud.. A systems analysis of the Baltic Sea, Ecol. Stud., 148, 75-112, 2001.

Boyanapalli, R., Bullerjahn, G. S., Pohl, C., Croot, P. L., Boyd, P. W., and McKay, R. M. L.: Luminescent whole-cell cyanobacterial bioreporter for measuring $\mathrm{Fe}$ availability in diverse marine environments, Appl. Environ. Microbiol., 73, 1019-1024, doi:10.1128/aem.01670-06, 2007.

Boyd, P. W., Jickells, T., Law, C. S., Blain, S., Boyle, E. A., Buesseler, K. O., Coale, K. H., Cullen, J. J., de Baar, H. J. W., Follows, M., Harvey, M., Lancelot, C., Levasseur, M., Owens, N. P. J., Pollard, R., Rivkin, R. B., Sarmiento, J., Schoemann, V., Smetacek, V., Takeda, S., Tsuda, A., Turner, S., and Watson, A. J.: Mesoscale Iron Enrichment Experiments 19932005: Synthesis and Future Directions, Science, 315, 612-617, doi:10.1126/science.1131669, 2007.

Brügmann, L., Bernard, P. C., and Vangrieken, R.: Geochemistry of Suspended Matter from the Baltic Sea 2 - Results of Bulk TraceMetal Analysis by AAS, Marine Chem., 38, 303-323, 1992.

Brügmann, L., Hallberg, R., Larsson, C., and Loffler, A.: Trace metal speciation in sea and pore water of the Gotland Deep, Baltic Sea, 1994, Appl. Geochem., 13, 359-368, 1998.

Bruland, K. W., Rue, E. L., and Smith, G. J.: Iron and macronutrients in California coastal upwelling regimes: Implications for diatom blooms, Limnol. Oceanogr., 46, 1661-1674, 2001.

Cabaj, A. and Kosakowska, A.: The marine diatom Cyclotella meneghiniana Ktzing as a producer of siderophore-like substances, Oceanological and Hydrobiological Studies, 34, 57-72, 2005.

Cabaj, A. and Kosakowska, A.: Iron-dependent growth of and siderophore production by two heterotrophic bacteria isolated from brackish water of the southern Baltic Sea, Microbiol. Res., 164, 570-577, 2009.

Bruland, K. W. and Lohan, M. C.: Controls of Trace Metals in Seawater, in: Treatise on Geochemistry, Pergamon, Oxford, 23-47, 2003.

Clarke, S. E., Stuart, J., and Sandersloehr, J.: Induction of Siderophore Activity in Anabaena spp and Its Moderation of Copper Toxicity, Appl. Environ. Microbiol., 53, 917-922, 1987.

Croot, P. L. and Johansson, M.: Determination of iron speciation by cathodic stripping voltammetry in seawater using the competing ligand 2-(2-thiazolylazo)-p-cresol (TAC), Electroanalysis, 12, 565-576, 2000.

Croot, P. L., Bowie, A. R., Frew, R. D., Maldonado, M. T., Hall, J. A., Safi, K. A., La Roche, J., Boyd, P. W., and Law, C. S.: Retention of dissolved iron and Fe-II in an iron induced Southern Ocean phytoplankton bloom, Geophys. Res. Lett., 28, 34253428, 2001.

Croot, P. L. and Laan, P.: Continuous shipboard determination of $\mathrm{Fe}(\mathrm{II})$ in polar waters using flow injection analysis with chemiluminescence detection, Anal. Chim. Acta, 466, 261-273, 2002.

Croot, P. L., Andersson, K., Ozturk, M., and Turner, D. R.: The distribution and speciation of iron along $6^{\circ} \mathrm{E}$ in the Southern
Ocean, Deep Sea Res. II,, 51, 2857-2879, 2004a.

Croot, P. L., Streu, P., Peeken, I., Lochte, K., and Baker, A. R.: Influence of the ITCZ on $\mathrm{H} 2 \mathrm{O} 2$ in near surface waters in the equatorial Atlantic Ocean, Geophys. Res. Lett., 31, L23S04, doi:10.1029/2004GL020154, 2004b.

Croot, P. L., Laan, P., Nishioka, J., Strass, V., Cisewski, B., Boye, M., Timmermans, K. R., Bellerby, R. G., Goldson, L., Nightingale, P., and de Baar, H. J. W.: Spatial and temporal distribution of $\mathrm{Fe}(\mathrm{II})$ and $\mathrm{H} 2 \mathrm{O} 2$ during EisenEx, an open ocean mescoscale iron enrichment, Marine Chem., 95, 65-88, 2005.

Croot, P. L., Passow, U., Assmy, P., Jansen, S., and Strass, V. H.: Surface active substances in the upper water column during a Southern Ocean Iron Fertilization Experiment (EIFEX), Geophys. Res. Lett., 34, L03612, doi:03610.01029/02006GL028080, 2007.

Croot, P. L., Bluhm, K., Schlosser, C., Streu, P., Breitbarth, E., Frew, R. D., and Ardelan, M. V.: Cycling of $\mathrm{Fe}(\mathrm{II})$ in Southern Ocean Iron Mesoscale Enrichment Experiments: EIFEX and SOFEX, Geophys. Res. Lett., 35, L19606, doi:19610.11029/12008GL035063, 2008.

Dahlqvist, R., Zhang, H., Ingri, J., and Davison, W.: Performance of the diffusive gradients in thin films technique for measuring $\mathrm{Ca}$ and $\mathrm{Mg}$ in freshwater, Anal. Chim. Acta, 460, 247-256, 2002.

Davison, W. and Zhang, H.: In-Situ Speciation Measurements of Trace Components in Natural-Waters Using Thin-Film Gels, Nature, 367, 546-548, 1994.

de Baar, H. J. W., Boyd, P. W., Coale, K. H., Landry, M. R., Tsuda, A., Assmy, P., Bakker, D. C. E., Bozec, Y., Barber, R. T., Brzezinski, M. A., Buesseler, K. O., Boye, M., Croot, P. L., Gervais, F., Gorbunov, M. Y., Harrison, P. J., Hiscock, W. T., Laan, P., Lancelot, C., Law, C. S., Levasseur, M., Marchetti, A., Millero, F. J., Nishioka, J., Nojiri, Y., van Oijen, T., Riebesell, U., Rijkenberg, M. J. A., Saito, H., Takeda, S., Timmermans, K. R., Veldhuis, M. J. W., Waite, A. M., and Wong, C. S.: Synthesis of iron fertilization experiments: From the Iron Age in the Age of Enlightenment, J. Geophys. Res., 110, C09S16, doi:10.1029/2004JC002601, 2005.

Dupont, C. L., Nelson, R. K., Bashir, S., Moffett, J. W., and Ahner, B. A.: Novel copper-binding and nitrogen-rich thiols produced and exuded by Emiliania huxleyi, Limnol. Oceanogr., 49, 1754 $1762,2004$.

Dyrssen, D. and Kremling, K.: Increasing hydrogen sulfide concentration and trace metal behavior in the anoxic Baltic waters, Marine Chem., 30, 193-204, 1990.

Finni, T., Kononen, K., Olsonen, R., and Wallstrom, K.: The history of cyanobacterial blooms in the Baltic Sea, AMBIO, 30, 172178, 2001.

Fonselius, S., Dyrssen, D., and Yhlen, B.: Determination of hydrogen sulfide, in: Methods of Seawater Analysis, edited by: Grasshoff, K., Kremling, K., and Ehrhard, M., Wiley-VCH, 91100, 1999.

Forsberg, J., Dahlqvist, R., Gelting-Nystrom, J., and Ingri, J.: Trace metal speciation in brackish water using diffusive gradients in thin films and ultrafiltration: Comparison of techniques, Environ. Sci. Technol., 40, 3901-3905, 2006.

Franck, V. M., Bruland, K. W., Hutchins, D. A., and Brzezinski, M. A.: Iron and zinc effects on silicic acid and nitrate uptake kinetics in three high-nutrient, low-chlorophyll (HNLC) regions, Mar. Ecol.-Prog. Ser., 252, 15-33, 2003. 
Gelting, J., Breitbarth, E., Stolpe, B., Hassellöv, M., and Ingri, J.: Fractionation of iron species and iron isotopes in the Baltic Sea euphotic zone, Biogeosciences Discuss., 6, 6491-6537, 2009, http://www.biogeosciences-discuss.net/6/6491/2009/.

Gerringa, L. J. A., Herman, P. M. J., and Poortvliet, T. C. W.: Comparison of the linear Van den Berg/Ruzic transformation and a non-linear fit of the Langmuir isotherm applied to $\mathrm{Cu}$ speciation data in the estuarine environment, Marine Chem., 48, 131-142, 1995.

Gerringa, L. J. A., Rijkenberg, M. J. A., Wolterbeek, H. T., Verburg, T. G., Boye, M., and de Baar, H. J. W.: Kinetic study reveals weak Fe-binding ligand, which affects the solubility of Fe in the Scheldt estuary, Marine Chem., 103, 30-45, 2007.

Gonzalez-Davila, M., Santana-Casiano, J. M., and Millero, F. J.: Competition between $\mathrm{O}-2$ and $\mathrm{H} 2 \mathrm{O} 2$ in the oxidation of $\mathrm{Fe}(\mathrm{II})$ in natural waters, J. Solution Chem., 35, 95-111, 2006.

Gustafsson, O., Widerlund, A., Andersson, P. S., Ingri, J., Roos, P., and Ledin, A.: Colloid dynamics and transport of major elements through a boreal river - brackish bay mixing zone, Marine Chem., 71, 1-21, 2000.

Hagström, A., Azam, F., Kuparinen, J., and Zweifel, U.-L.: Pelagic plankton growth and resource limitations in the Baltic Sea, in: Ecol. Stud. A systems analysis of the Baltic Sea, Ecol. Stud., 148, 177-210, 2001.

Hansen, H. P.: Determination of oxygen, in: Methods of Seawater Analysis, edited by: Grasshoff, K., Kremling, K., and Ehrhard, M., Wiley-VCH, 75-89, 1999.

Hassellöv, M.: Relative molar mass distributions of chromophoric colloidal organic matter in coastal seawater determined by Flow Field-Flow Fractionation with UV absorbance and fluorescence detection, Marine Chem., 94, 11-123, 2005.

Hjalmarsson, S., Wesslander, K., Anderson, L. G., Omstedt, A., Perttilä, M., and Mintrop, L.: Distribution, long-term development and mass balance calculation of total alkalinity in the Baltic Sea, Cont. Shelf Res., 28, 593-601, 2008.

Hopkinson, B. M., and Barbeau, K. A.: Organic and redox speciation of iron in the eastern tropical North Pacific suboxic zone, Marine Chem., 106, 2-17, 2007.

Humble, A. V., Gadd, G. M., and Codd, G. A.: Binding of copper and zinc to three cyanobacterial microcystins quantified by differential pulse polarography, Water Res., 31, 1679-1686, 1997.

Hutchins, D. A., DiTullio, G. R., Zhang, Y., and Bruland, K. W.: An iron limitation mosaic in the California upwelling regime, Limnol. Oceanogr., 43, 1037-1054, 1998.

Ingri, J., Nordling, S., Larsson, J., Ronnegard, J., Nilsson, N., Rodushkin, I., Dahlqvist, R., Andersson, P., and Gustafsson, O.: Size distribution of colloidal trace metals and organic carbon during a coastal bloom in the Baltic Sea, Marine Chem., 91, 117130, 2004.

Johansson, M., Gorokhova, E., and Larsson, U.: Annual variability in ciliate community structure, potential prey and predators in the open northern Baltic Sea proper, J. Plankton Res., 26, 67-80, doi:10.1093/plankt/fbg115, 2004.

Johnson, K. S., Coale, K. H., Elrod, V. A., and Tindale, N. W.: Iron photochemistry in seawater from the equatorial Pacific, Marine Chem., 46, 319-334, 1994.

Kaebernick, M. and Neilan, B. A.: Ecological and molecular investigations of cyanotoxin production, FEMS Microbiol. Ecol., 35, $1-9,2006$.
Kahru, M., Savchuk, O. P., and Elmgren, R.: Satellite measurements of cyanobacterial bloom frequency in the Baltic Sea: interannual and spatial variability, Mar. Ecol. Prog. Ser., 343, 15-23, doi:10.3354/meps06943, 2007.

Kieber, R. J., Williams, K., Willey, J. D., Skrabal, S., and Avery, G. B.: Iron speciation in coastal rainwater: concentration and deposition to seawater, Marine Chem., 73, 83-95, 2001.

Kieber, R. J., Skrabal, S. A., Smith, B. J., and Willey, J. D.: Organic complexation of $\mathrm{Fe}(\mathrm{II})$ and its impact on the redox cycling of iron in rain, Environ. Sci. Technol., 39, 1576-1583, doi:10.1021/es040439h, 2005.

Kononen, K., Kuparinen, J., Mäkelä, K., Laanemets, J., Pavelson, J., and Nômmann, S.: Initiation of cyanobacterial blooms in a frontal region at the entrance to the Gulf of Finland, Baltic Sea., Limnol. Oceanogr., 41, 98-112, 1996.

Kuma, K., Nakabayashi, S., Suzuki, Y., Kudo, I., and Matsunaga, K.: Photo-Reduction of Fe (III) by Dissolved OrganicSubstances and Existence of Fe (II) in Seawater During Spring Blooms, Marine Chem., 37, 15-27, 1992.

Kuma, K., Nakabayashi, S., and Matsunaga, K.: Photoreduction of Fe(III) by Hydroxycarboxylic Acids in Seawater, Water Res., 29, 1559-1569, 1995.

Kustka, A., Carpenter, E. J., and Sanudo-Wilhelmy, S. A.: Iron and marine nitrogen fixation: progress and future directions, Res. Microbiol., 153, 255-262, 2002.

Kustka, A., Sanudo-Wilhelmy, S., Carpenter, E. J., Capone, D. G., and Raven, J. A.: A revised estimate of the iron use efficiency of nitrogen fixation, with special reference to the marine cyanobacterium Trichodesmium spp. (Cyanophyta), J. Phycol., 39, 12-25, 2003a.

Kustka, A. B., Sanudo-Wilhelmy, S. A., Carpenter, E. J., Capone, D., Burns, J., and Sunda, W. G.: Iron requirements for dinitrogen- and ammonium-supported growth in cultures of Trichodesmium (IMS 101): Comparison with nitrogen fixation rates and iron: carbon ratios of field populations, Limnol. Oceanogr., 48, 1869-1884, 2003b.

Kustka, A. B., Shaked, Y., Milligan, A. J., King, D. W., and Morel, F. M. M.: Extracellular production of superoxide by marine diatoms: Contrasting effects on iron redox chemistry and bioavailability, Limnol. Oceanogr., 50, 1172-1180, 2005.

Laglera, L. M. and van den Berg, C. M. G.: Copper complexation by thiol compounds in estuarine waters, Marine Chem., 82, 7189, 2003.

Larsson, U., Hajdu, S., Walve, J., and Elmgren, R.: Baltic Sea nitrogen fixation estimated from the summer increase in upper mixed layer total nitrogen, Limnol. Oceanogr., 46, 811-820, 2001.

Lewis, E. and Wallace, D. W. R.: Program Developed for $\mathrm{CO}_{2}$ System Calculations. ORNL/CDIAC-105. Carbon Dioxide Information Analysis Center, Oak Ridge National Laboratory, U.S. Department of Energy, Oak Ridge, Tenessee, 1998.

Maldonado, M. T. and Price, N. M.: Utilization of iron bound to strong organic ligands by plankton communities in the subarctic Pacific Ocean, Deep-Sea Res. II, 46, 2447-2473, 1999.

Maldonado, M. T. and Price, N. M.: Nitrate regulation of Fe reduction and transport by Fe-limited Thalassiosira oceanica, Limnol. Oceanogr., 45, 814-826, 2000.

Maldonado, M. T. and Price, N. M.: Reduction and transport of organically bound iron by Thalassiosira oceanica (Bacillariophyceae), J. Phycol., 37, 298-309, 2001. 
Maldonado, M. T., Strzepek, R. F., Sander, S., and Boyd, P. W.: Acquisition of iron bound to strong organic complexes, with different Fe binding groups and photochemical reactivities, by plankton communities in Fe-limited subantarctic waters, Global Biogeochem. Cy., 19, GB4S23, doi:10.1029/2005GB002481, 2005.

Mawji, E., Gledhill, M., Milton, J. A., Tarran, G. A., Ussher, S., Thompson, A., Wolff, G. A., Worsfold, P. J., and Achterberg, E. P.: Hydroxamate Siderophores: Occurrence and Importance in the Atlantic Ocean, Environ. Sci. Technol., 42, 8675-8680, doi:10.1021/es801884r, 2008.

Meier, H. E. M.: Modeling the pathways and ages of inflowing saltand freshwater in the Baltic Sea, Estuar. Coast. Shelf S., 74, 610 627, doi:10.1016/j.ecss.2007.05.019, 2007.

Menden-Deuer, S. and Lessard, E. J.: Carbon to volume relationships for dinoflagellates, diatoms, and other protist plankton, Limnol. Oceanogr., 45, 569-579, 2000.

Millero, F. J., Sotolongo, S., and Izaguirre, M.: The oxidation kinetics of Fe(II) in seawater, Geochim. Cosmochim. Acta, 51, 793801, 1987.

Millero, F. J. and Sotolongo, S.: The oxidation of Fe(II) with $\mathrm{H} 2 \mathrm{O} 2$ in seawater, Geochim. Cosmochim. Acta, 53, 1867-1873, 1989.

Moffett, J. W., Goeffert, T. J., and Naqvi, S. W. A.: Reduced iron associated with secondary nitrite maxima in the Arabian Sea, Deep-Sea Res. I, 54, 1341-1349, 2007.

Morel, F. M. M., Kustka, A. B., and Shaked, Y.: The role of unchelated $\mathrm{Fe}$ in the iron nutrition of phytoplankton, Limnol. Oceanogr., 53, 400-404, 2008.

Nagai, T., Imai, A., Matsushige, K., Yokoi, K., and Fukushima, T.: Dissolved iron and its speciation in a shallow eutrophic lake and its inflowing rivers, Water Res., 41, 775-784, 2007.

O'Sullivan, D. W., Hanson, A. K., Miller, W. L., and Kester, D. R.: Measurement of $\mathrm{Fe}(\mathrm{II})$ in surface water of the equatorial Pacific, Limnol. Oceanogr., 36, 1727-1741, 1991.

Öztürk, M., Steinnes, E., and Sakshaug, E.: Iron Speciation in the Trondheim Fjord from the Perspective of Iron Limitation for Phytoplankton, Estuar. Coas. Shelf S., 55, 197-212, 2002.

Pamatmat, M. M.: Non-photosynthetic oxygen production and nonrespiratory oxygen uptake in the dark: a theory of oxygen dynamics in plankton communities, Mar. Biol., 129, 735-746, 1997.

Pempkowiak, J.: The origin of humic substances in the baltic sea evaluated on the basis of chemical properties, Marine Chem., 12, 234-234, 1983.

Pempkowiak, J.: Complexing properties of humic substances isolated from sea water; the contribution of these substances to complexing capacities of water from the Baltic Sea and geochemical implications of this phenomenon, in: Humic Substances in the Aquatic and Terrestrial Environment, edited by: Allard, B., Borén, H., and Grimvall, A., Springer, Berlin/Heidelberg, 339348, doi:310.1007/BFb0010485, 1991.

Pettersson, C., Allard, B., and Borén, H.: River Discharge of Humic Substances and Humic-bound Metals to the Gulf of Bothnia, Estuar. Coast. Shelf S., 44, 533-541, 1997a.

Pettersson, C., Rahm, L., Allard, B., and Boren, H.: Photodegradation of aquatic humic substances: An important factor for the Baltic carbon cycle?, Boreal Environ. Res., 2, 209-215, $1997 \mathrm{~b}$.

Ploug, H.: Cyanobacterial surface blooms formed by Aphanizomenon sp. and Nodularia spumigena in the Baltic Sea: Small-scale fluxes, $\mathrm{pH}$, and oxygen microenvironments, Limnol.
Oceanogr., 53, 914-921, 2008.

Pohl, C. and Hennings, U.: The effect of redox processes on the partitioning of $\mathrm{Cd}, \mathrm{Pb}, \mathrm{Cu}$, and $\mathrm{Mn}$ between dissolved and particulate phases in the Baltic Sea, Marine Chem., 65, 41-53, 1999.

Pohl, C., Löffler, A., and Hennings, U.: A sediment trap flux study for trace metals under seasonal aspects in the stratified Baltic Sea (Gotland Basin; 57 ${ }^{\circ} 19.20^{\prime} \mathrm{N}$; $20^{\circ}$ 03.00’E), Marine Chem., 84, 143-160, 2004.

Pohl, C. and Hennings, U.: The coupling of long-term trace metal trends to internal trace metal fluxes at the oxic-anoxic interface in the Gotland Basin (57 degrees 19, 20' N; 20 degrees $\left.03,00^{\prime} \mathrm{E}\right)$ Baltic Sea, J. Marine Syst., 56, 207-225, doi:10.1016/j.jmarsys.2004.10.001, 2005.

Pohl, C., Loffler, A., Schmidt, M., and Seifert, T.: A trace metal $(\mathrm{Pb}, \mathrm{Cd}, \mathrm{Zn}, \mathrm{Cu})$ balance for surface waters in the eastern Gotland Basin, Baltic Sea, J. Marine Syst., 60, 381-395, doi:10.1016/j.jmarsys.2006.02.003, 2006.

Rijkenberg, M. J. A., Gerringa, L. J. A., Carolus, V. E., Velzeboer, I., and de Baar, H. J. W.: Enhancement and inhibition of iron photoreduction by individual ligands in open ocean seawater, Geochim. Cosmochim. Acta, 70, 2790-2805, doi:2710.1016/j.gca.2006.2703.2004, 2006a.

Rijkenberg, M. J. A., Gerringa, L. J. A., Velzeboer, I., Timmermans, K. R., Buma, A. G. J., and de Baar, H. J. W.: Iron-binding ligands in Dutch estuaries are not affected by UV induced photochemical degradation, Marine Chem., 100, 11-23, 2006b.

Rodushkin, I. and Ruth, T.: Determination of trace metals in estuarine and sea-water reference materials by high resolution inductively coupled plasma mass spectrometry, J. Anal. Atom. Spectrom., 12, 1181-1185, 1997.

Rose, A. L. and Waite, T. D.: Kinetics of iron complexation by dissolved natural organic matter in coastal waters, Marine Chem., 84, 85-103, doi:10.1016/s0304-4203(03)00113-0, 2003.

Rose, A. L., Salmon, T. P., Lukondeh, T., Neilan, B. A., and Waite, T. D.: Use of superoxide as an electron shuttle for iron acquisition by the marine cyanobacterium Lyngbya majuscula, Environ. Sci. Technol., 39, 3708-3715, doi:10.1021/es048766c, 2005.

Roy, E. G., Wells, M. L., and King, D. W.: Persistence of iron(II) in surface waters of the western subarctic Pacific, Limnol. Oceanogr., 53, 89-98, 2008.

Rue, E. L. and Bruland, K. W.: Complexation of iron(III) by natural organic ligands in the Central North Pacific as determined by a new competitive ligand equilibration/adsorptive cathodic stripping voltammetric method, Marine Chem., 50, 117-138, 1995.

Salmon, T. P., Rose, A. L., Neilan, B. A., and Waite, T. D.: The FeL model of iron acquisition: Nondissociative reduction of ferric complexes in the marine environment, Limnol. Oceanogr., 51, 1744-1754, 2006.

Sander, S., Mosley, L. M., and Hunter, K. A.: Investigation of interparticle forces in natural waters: Effects of adsorbed humic acids on iron oxide and alumina surface properties, Environ. Sci. Technol., 38, 4791-4796, doi:10.1021/es049602z, 2004.

Santana-Casiano, J. M., Gonzalez-Davila, M., and Millero, F. J.: The role of $\mathrm{Fe}(\mathrm{II})$ species on the oxidation of $\mathrm{Fe}(\mathrm{II})$ in natural waters in the presence of $\mathrm{O}_{2}$ and $\mathrm{H}_{2} \mathrm{O}_{2}$, Marine Chem., 99, 7082, 2006

Sanudo-Wilhelmy, S. A., Kustka, A. B., Gobler, C. J., Hutchins, D. A., Yang, M., Lwiza, K., Burns, J., Capone, D. G., Ravenk, J. A., and Carpenter, E. J.: Phosphorus limitation of nitrogen fixation 
by Trichodesmium in the central Atlantic Ocean, Nature, 411, 66-69, 2001.

Scally, S., Davison, W., and Zhang, H.: Diffusion coefficients of metals and metal complexes in hydrogels used in diffusive gradients in thin films, Anal. Chim. Acta, 558, 222-229, doi:210.1016/j.aca.2005.1011.1020, 2006.

Schubert, B., Dahke, S., and Schoor, A.: Effects of short-term manipulations in iron nutrition of Nodularia spumigena from near-coast blooms (southern Baltic Sea), 6th Baltic Sea Science Congress/Joint Meeting of the Baltic Marine Biologists/Baltic Oceanographers/Baltic Sea Geologists, Rostock, GERMANY, ISI:000262091600011, S97-S107, 2007.

Shaked, Y., Kustka, A. B., Morel, F. M. M., and Erel, Y.: Simultaneous determination of iron reduction and uptake by phytoplankton, Limnol. Oceanogr.-Meth., 2, 137-145, 2004.

Shaked, Y., Kustka, A. B., and Morel, F. M. M.: A general kinetic model for iron acquisition by eukaryotic phytoplankton, Limnol. Oceanogr., 50, 872-882, 2005.

Sholkovitz, E. R. and Coplan, D.: The coagulation, solubility and adsorption properties of $\mathrm{Fe}, \mathrm{Mu}, \mathrm{Cu}, \mathrm{Ni}, \mathrm{Cd}, \mathrm{Co}$ and humic acids in a river water, Geochim. Cosmochim. Acta, 45, 181-189, 1981.

Skoog, A., Wedborg, M., and Fogelqvist, E.: Photobleaching of fluorescence and the organic carbon concentration in a coastal environment, Marine Chem., 55, 333-345, 1996.

Stal, L. J., Staal, M., and Villbrandt, M.: Nutrient control of cyanobacterial blooms in the Baltic Sea, Aquat. Microb. Ecol., 18, 165-173, 1999.

Stal, L. J., Albertano, P., Bergman, B., von Brockel, K., Gallon, J. R., Hayes, P. K., Sivonen, K., and Walsby, A. E.: BASIC: Baltic Sea cyanobacteria. An investigation of the structure and dynamics of water blooms of cyanobacteria in the Baltic Sea - responses to a changing environment, Cont. Shelf Res., 23, 1695-1714, doi:10.1016/j.csr.2003.06.001, 2003.

Stedmon, C. A., Thomas, D. N., Granskog, M., Kaartokallio, H., Papadimitriou, S., and Kuosa, H.: Characteristics of dissolved organic matter in Baltic coastal sea ice: Allochthonous or autochthonous origins?, Environ. Sci. Technol., 41, 7273-7279, doi:10.1021/es071210f, 2007.

Steigenberger, S., Statham, P. J., Völker, C., and Passow, U.: The role of polysaccharides and diatom exudates in the redox cycling of $\mathrm{Fe}$ and the photoproduction of hydrogen peroxide in coastal seawaters, Biogeosciences Discuss., 6, 7789-7819, 2009, http://www.biogeosciences-discuss.net/6/7789/2009/.

Stolte, W., Balode, M., Carlsson, P., Grzebyk, D., Janson, S., Lips, I., Panosso, R., Ward, C. J., and Graneli, E.: Stimulation of nitrogen-fixing cyanobacteria in a Baltic Sea plankton community by land-derived organic matter or iron addition, Mar. Ecol. Prog. Ser., 327, 71-82, 2006.

Strady, E., Pohl, C., Yakushev, E. V., Kruger, S., and Hennings, U.: PUMP-CTD-System for trace metal sampling with a high vertical resolution. A test in the Gotland Basin, Baltic Sea, Chemosphere, 70, 1309-1319, 2008.
Sunda, W. G. and Huntsman, S. A.: Iron uptake and growth limitation in oceanic and coastal phytoplankton, Marine Chem., 50, 189-206, 1995.

Sunda, W. G.: Bioavailability and Bioaccumulation of Iron in the Sea, in: The Biogeochemistry of Iron in Seawater, edited by: Turner, D. R., and Hunter, K. A., John Wiley and Sons Ltd., West Sussex, England, 396 pp., 2001.

Utkilen, H. and Gjolme, N.: Iron-Stimulated Toxin Production in Microcystis-Aeruginosa, Appl. Environ. Microbiol., 61, 797800, 1995.

Vähätalo, A. V. and Zepp, R. G.: Photochemical mineralization of dissolved organic nitrogen to ammonium in the Baltic Sea, Environ. Sci. Technol., 39, 6985-6992, doi:10.1021/es050142z, 2005.

Walve, J. and Larsson, U.: Blooms of Baltic Sea Aphanizomenon sp (cyanobacteria) collapse after internal phosphorus depletion, Aquat. Microb. Ecol., 49, 57-69, doi:10.3354/ame01130, 2007.

Wells, M. L. and Mayer, L. M.: The Photoconversion of Colloidal Iron Oxyhydroxides in Seawater, Deep-Sea Res. I, 38, 13791395, 1991.

Wells, M. L., Mayer, L. M., Donard, O. F. X., Sierra, M. M. D., and Ackelson, S. G.: The photolysis of colloidal iron in the oceans, Nature, 353, 248-250, 1991.

Wells, M. L.: A neglected dimension, Nature, 391, 530-531, 1998.

Wells, M. L., Smith, J. G., and Bruland, K. W.: The distribution of colloidal and particulate bioactive metals in Narragansett Bay, RI Marine Chem., 71, 143-163, 2000.

Wilhelm, S. W., Maxwell, D. P., and Trick, C. G.: Growth, iron requirements, and siderophore production in iron-limited Synechococcus PCC 7002, Limnol. Oceanogr., 41, 89-97, 1996.

Willey, J. D., Kieber, R. J., Seaton, P. J., and Miller, C.: Rainwater as a source of $\mathrm{Fe}(\mathrm{II})$-stabilizing ligands to seawater, Limnol. Oceanogr., 53, 1678-1684, 2008.

Willey, J. D., Kieber, R. J., and Yavari, J. R.: Fe(II) in coastal rainwater: Changing stability and concentrations, Aquat. Sci., 71, 144-150, doi:10.1007/s00027-009-9176-4, 2009.

Yuan, J. C. and Shiller, A. M.: Determination of subnanomolar levels of hydrogen peroxide in seawater by reagent-injection chemiluminescence detection, Anal. Chem., 71, 1975-1980, 1999.

Zhang, H. and Davison, W.: Performance-Characteristics of Diffusion Gradients in Thin-Films for the in-Situ Measurement of Trace-Metals in Aqueous-Solution, Anal. Chem., 67, 33913400, 1995.

Zhang, H. and Davison, W.: Diffusional characteristics of hydrogels used in DGT and DET techniques, Anal. Chim. Acta, 398, 329340, 1999. 